\title{
Clean Production of Biofuel from Waste Cooking Oil to Reduce Emissions, Fuel Cost, and Respiratory Disease Hospitalizations
}

\author{
José Carlos Curvelo Santana ${ }^{1,2, *}$, Amanda Carvalho Miranda ${ }^{1}$, Luane Souza ${ }^{2}$, Charles Lincoln Kenji Yamamura ${ }^{1}$, \\ Diego de Freitas Coelho ${ }^{3}{ }^{\circ}$, Elias Basile Tambourgi ${ }^{3}{ }^{\circledR}$, Fernando Tobal Berssaneti ${ }^{1}{ }^{\mathbb{D}}$ and Linda Lee Ho ${ }^{1}$ \\ 1 Department of Production Engineering, University of São Paulo, São Paulo 05508-010, SP, Brazil; \\ mirandaca1@hotmail.com (A.C.M.); charles.yamamura@usp.br (C.L.K.Y.); \\ fernando.berssaneti@usp.br (F.T.B.); lindalee@usp.br (L.L.H.) \\ 2 Industrial Engineering Post Graduation Program, Federal University of ABC, São Bernardo do Campo, \\ São Paulo 09606-045, SP, Brazil; luane.souza@aluno.ufabc.edu.br \\ 3 School of Chemical Engineering, State University of Campinas, São Paulo 13083-970, SP, Brazil; \\ diegofcoelho@gmail.com (D.d.F.C.); eliastam@feq.unicamp.br (E.B.T.) \\ * Correspondence: jose.curvelo@ufabc.edu.br
}

Citation: Santana, J.C.C.; Miranda, A.C.; Souza, L.; Yamamura, C.L.K.; Coelho, D.d.F.; Tambourgi, E.B.; Berssaneti, F.T.; Ho, L.L. Clean Production of Biofuel from Waste Cooking Oil to Reduce Emissions, Fuel Cost, and Respiratory Disease Hospitalizations. Sustainability 2021, 13, 9185. https://doi.org/10.3390/ su13169185

Academic Editors: Geraldo Cardoso de Oliveira Neto, Wagner

Cezar Lucato, Marlene Amorim and Vikas Kumar

Received: 4 June 2021

Accepted: 3 August 2021

Published: 16 August 2021

Publisher's Note: MDPI stays neutral with regard to jurisdictional claims in published maps and institutional affiliations.

Copyright: (c) 2021 by the authors. Licensee MDPI, Basel, Switzerland. This article is an open access article distributed under the terms and conditions of the Creative Commons Attribution (CC BY) license (https:/ / creativecommons.org/licenses/by/ $4.0 /)$.

\begin{abstract}
Renewable energies are cleaner forms of energy, and their use, has intensified in recent decades. Thus, this work presents a proposal for reducing the emissions, fuel cost, and respiratory disease hospitalizations using environmental cost accounting principles to produce biodiesel production from waste frying oil. In our methodology, we conducted surveys, and collected waste cooking oil samples from local households and restaurants in São Paulo city, Brazil. Then, we produced biodiesel using these samples. Data on air pollutants were collected and correlated with the number of hospitalizations for respiratory diseases and their costs. Our results indicate that 330,000 respiratory disease hospitalizations were recorded in São Paulo city between 2009 and 2018, and the total cost for the Brazilian government reached US \$117 million. Improving the city air quality by switching from fossil fuels to biodiesel could reduce the annual number of hospitalizations to 9880 and cost US $\$ 3.518$ million, because the amount of pollutants emitted from burning fossil fuels was positively correlated with the number of respiratory disease hospitalizations and their costs. Moreover, the emission rates of particulate matter with particles less than 10 and $2.5 \mu \mathrm{m}$ in diameter exceeded the World Health Organization limits throughout the study period. Using the survey data, we estimated that the average monthly quantity of waste cooking oil was $9794.6 \mathrm{~m}^{3}$, which could generate $9191.2 \mathrm{~m}^{3}$ of biodiesel and produce $239,713 \mathrm{t} \mathrm{CO}_{2}$ of carbon credits. Environmental cost accounting revealed that it would be possible to achieve an annual profit of approximately US $\$ 300$ million from the sale of excess biodiesel, carbon credits, and glycerine, and fuel acquisition savings which could improve the image of São Paulo city and quality of life of its residents. Thus, we present this as a way to reduce cost and hospitalizations, and increase the number of available hospital beds for other diseases, such as COVID-19.
\end{abstract}

Keywords: environmental cost accounting; human health care; greenhouse gas emission; biodiesel; waste cooking oil; air pollution

\section{Introduction}

\subsection{Advantages and Disadvantages of Diesel Oil}

A clean technology practice is presented in this work, which contributes to sustainable development by using a renewable fuel that is a cleaner technology than fossil fuels, as it reduces the number of polluting gases in the atmosphere, improving the health and quality of life of citizens. Among the main barriers, the proof of the economic or environmental feasibility of the proposals is cited, which is easily solved using the theory of environmental cost accounting [1-3]. The use of renewable energy sources is one of the cleanest ways the energy sector uses to contribute to sustainable development. Thus, the switch from 
the source of fossil fuels (more pollutants) to renewable sources (e.g., biodiesel) has been intensified in recent decades [4-7].

Diesel engines, which are the most popular engines worldwide, are used in trucks, buses, trains, ships, and industrial off-road vehicles, as well as power generators and industrial machinery and equipment $[8,9]$. Their low operating costs, energy efficiency, high durability, and reliability have contributed to their high usability; however, diesel engines also present disadvantages. Diesel exhaust is a complex mixture of hydrocarbons, gases, sulfur, and particulates, that is produced during the combustion of diesel oil; moreover, diesel exhaust is one of the major contributors to the total aerosol mass and particulate matter (PM) in urban agglomerations, and is associated with high-traffic areas $[7,9,10]$. Although less than $1 \%$ of the exhaust gases from diesel engines are pollutants, they are responsible for severe environmental and health problems [8]. Thus, expanding the use of diesel engines has been contributing to the increase in atmospheric pollutant emissions and the worsening air quality and human health [9]. In addition, Hajjari et al. [11] stated that the gases emitted from burning diesel oil were responsible for $75.1 \%, 63.7 \%, 43 \%, 36.3 \%$, and $1.8 \%$ of the atmospheric emissions of PM, nitrogen dioxide $\left(\mathrm{NO}_{2}\right)$, nitrogen oxides (NOx), sulfur dioxide $\left(\mathrm{SO}_{2}\right)$, and carbon monoxide $(\mathrm{CO})$, respectively.

Selley et al. [12] indicated that the combustion of biodiesel instead of diesel oil could be used to reduce the diesel engine-related toxic emissions, because the oxygen content of biodiesel is higher than that of diesel oil; moreover, the combustion of biodiesel is complete, it does not generate aromatic or sulfurous compounds, and the amounts of unburned hydrocarbons, polycyclic aromatic hydrocarbons, CO, and PM generated by burning biodiesel are $90 \%, 75-90 \%, 43 \%$, and $55 \%$, respectively, lower than those generated by burning diesel oil.

Da Silva et al. [13], Reis et al. [14], and Silva Filho et al. [15] used biodiesel in power generators and noted that there were no significant differences between the amounts of power generated using the same amount of biodiesel blends and diesel oil. In addition, the greenhouse gas emissions associated with biodiesel were at least $30 \%$ lower than those associated with diesel oil. Biodiesel has also been tested in agricultural tractor engines, and the results indicated that engine efficiency achieved when using blends of up to $50 \%$ biodiesel was similar to that achieved when using diesel oil $[13,14]$.

Hasan and Rhaman [16] demonstrated that the use of different percentages of biodiesel produced from waste oils shortened the ignition time of combustion engines, which promoted the reaction time of the mixtures and eventually reduced the emission level of unburned hydrocarbons. Furthermore, Hansan and Rhaman [17] indicated that compared to diesel oil, biodiesel obtained from waste oils provided shorter ignition delays, lower heat release rates, and slightly higher efficiency; in addition, to obtain a reduction in hydrocarbons, CO, and PM emissions. Pereira et al. [9] reported that the biggest benefit of using biodiesel was the significantly lower emission of pollutants, such as PM, CO, hydrocarbons, and NOx, compared to those generated by diesel oil.

Silva Filho et al. [15] and Chua et al. [18] demonstrated that using waste cooking oil to produce biodiesel was environmentally beneficial, and the $\mathrm{SO}_{2}, \mathrm{NOx}, \mathrm{N}_{2} \mathrm{O}, \mathrm{CO}_{2}, \mathrm{PM}$, volatile organic compounds (VOCs), and methane $\left(\mathrm{CH}_{4}\right)$ emissions generated by burning biodiesel were $100 \%, 97.95 \%, 96.08 \%, 95.42 \%, 99.99 \%, 91.52 \%$, and $82.28 \%$, respectively, lower than those generated by burning diesel oil. This corroborated the importance of using waste cooking oil to produce biodiesel, because biodiesel is renewable, more sustainable than its source, and more environmentally friendly than fossil fuel. Moreover, as waste cooking oil is a waste, it does not compete with edible oil in elevation and consumption [15], does not require an increase in soybean acreage, and does not contribute to the need for deforestation to increase acreage $[15,19]$. 
Santos et al. [20] indicated that Brazilian biodiesel consisted exclusively of soybean biodiesel and argued the need for diversifying its production to involve other oil sources, and thus, as reported by Živković et al. [21], the social benefits of biodiesel production would extend to the poor Brazilian communities [22,23].

Brodny and Tutak [24] indicated that gaseous pollutants are one of the most dangerous types of pollutants for human health, because of their lasting negative effects on human health and life expectancy. In addition, more than 7 million annual premature deaths are associated with gaseous pollutants, and therefore, they represent one of the biggest risks to human health worldwide [10].

Furthermore, De Marco et al. [25] reported that in 2005, particulate matter with particles less than $10 \mu \mathrm{m}$ in diameter $\left(\mathrm{PM}_{10}\right)$ and $\mathrm{NO}_{2}$ induced approximately 58,000 cardiovascularand respiratory disease-related premature deaths in Italy. In China, more than one million annual premature deaths are attributed to air pollution, the pollution-related disease records increased by $33 \%$, and the number of disabled individuals reached 76 million and continues to increase [26]. Furthermore, Yu et al. [26] indicated that Northern, Central, and Southern China are the regions where human health is more severely affected owing to $\mathrm{PM}$, particulate matter with particles less than $2.5 \mu \mathrm{m}$ in diameter $\left(\mathrm{PM}_{2.5}\right), \mathrm{NO}_{2}$, and $\mathrm{SO}_{2}$ pollution, which is attributed to the large number of vehicles and human activities in these highly populated regions.

According to the World Health Organization [10], improving air quality by replacing fossil fuel with renewable fuels, such as biodiesel, could reduce pollutant emissions and respiratory disease hospitalizations by $30 \%$; moreover, respiratory disease-associated mortality could also decrease significantly.

According to the Sistema Unico de Saúde (SUS) database, air pollution cost in Brazil between 1993 and 1995 exceeded USD 2 million [27]. The money was spent on treating patients who developed diseases directly related to the excess pollutants. This amount of money could have covered the cost of 784,000 medical consultations or 10,100 births in Brazilian Health System (SUS)-affiliated hospitals. Research has reported the effects of gaseous emissions on human health in Brazil, as well as correlating the number of pollutant-related respiratory disease hospitalizations with their costs for the public health system SUS [28-34]. Thus, the WHO [10] has estimated that, currently, in Brazil, an average of 22,000 people lose their lives prematurely annually, owing to exposure to environmental pollutants, particularly in urban agglomerations.

In addition to the various studies that make up the WHO data [10], several authors have demonstrated the benefits of switching from current fuel (diesel oil) to biodiesel in diesel engines. Because in addition to reducing emissions of gaseous pollutants [35], there is a reduction in hospitalization rates for respiratory diseases [36,37]. Moreover, according to the ANP, vehicles that use diesel engines are less than $15 \%$ of the total, but correspond to more than $40 \%$ of the total gas emissions in Brazil [38].

Thus, this study aimed to present a proposal for reducing emissions, fuel cost, and respiratory disease hospitalizations using environmental cost accounting principles to produce biodiesel from waste cooking oil collected in São Paulo city. A questionnaire was used to survey individuals and restaurant owners, and residual frying oils were collected during the interviews. Data on gaseous emissions, respiratory disease hospitalizations, and their costs were also collected from official health and environmental agencies, and the numbers were correlated to determine how much the hospitalizations and their costs could be reduced via replacing diesel oil with biodiesel. 


\subsection{Pathologies Associated with Air Pollution}

The main risk groups that are significantly affected by air pollution and are more susceptible to develop health problems, such as respiratory diseases, are children and the elderly. Moreover, chronic exposure to $\mathrm{PM}_{2.5}$ emitted via the burning of fossil fuels, particularly those containing lead, increases the risk of heart and respiratory diseases, and could even cause lung cancer. The high air pollution in large urban centers has also been associated with increased risk factors for cardiovascular diseases, such as cardiac arrhythmias, vasoconstriction and hypertension, myocardial and cerebral ischemia, and the progression of arteriosclerosis [39].

Individuals most susceptible to diseases caused by pollutant emissions are children, the elderly, people with chronic diseases, and those with genetic susceptibility. In addition, pollutants can affect the human fetuses during pregnancy, causing intrauterine growth delays, prematurity, low birth weight, and in the most severe cases, congenital anomalies, and intrauterine or perinatal death [37].

The effects of air pollution on people's health have been researched worldwide, and scholars have attempted to establish the relationship between the photochemical effects of air and the health of the respiratory system and/or allergic conditions. Kunzli et al. [38] reported the increased asthma incidence in adults living in high-traffic regions in Switzerland. Gehring et al. [40] associated the increase in $\mathrm{PM}_{2.5}$ levels with the increased asthma incidence in eight-year-old children.

De Marco et al. [25] and Yu et al. [28] reported that $\mathrm{PM}_{10}$ and $\mathrm{NO}_{2}$ emissions induced premature deaths, due to cardiovascular and respiratory diseases. Ko et al. [41] associated the increased number of chronic obstructive pulmonary disease (COPD) hospitalizations with increased $\mathrm{SO}_{2}, \mathrm{NO}_{2}, \mathrm{PM}_{2.5}$, and $\mathrm{PM}_{10}$ emissions. Andersen et al. [42] and $\mathrm{Hu}$ et al. [43] also reported the increase in the number of COPD hospitalizations owing to the increased $\mathrm{NO}_{2}$ emissions and in the emission of pollutants from biomass burning.

Reis et al. [14] noted a very high incidence of lung cancer with $\mathrm{PM}_{2.5}$ emissions. Ghering et al. [40] and Pandya et al. [44] reported that high $\mathrm{PM}_{2.5}$ levels were associated with the increase in the number of cases of bronchial asthma and allergic respiratory diseases owing to excessive exposure to $\mathrm{PM}_{10}$ from burning fuels, particularly diesel oil [44-50]. $\mathrm{PM}_{2.5}$ is also associated with the increase in the systolic blood pressure of hypertensive and/or diabetic outdoor workers [20,45-53]. Table 1 summarizes the symptoms and diseases that affect the respiratory tract and that are caused by exposure to gases emitted by burning fossil fuels. 
Table 1. Gaseous pollutants and their effects on human health.

\begin{tabular}{|c|c|c|c|c|c|c|}
\hline WHO Standard & $\begin{array}{c}\mathrm{PM}_{10} \\
50 \mu \mathrm{g} / \mathrm{m}^{3} \text { per } 24 \mathrm{~h} \\
\text { or } 20 \mu \mathrm{g} / \mathrm{m}^{3} \text { per Year }\end{array}$ & $\begin{array}{c}\mathrm{PM}_{2.5} \\
25 \mu \mathrm{g} / \mathrm{m}^{3} \text { per } 24 \mathrm{~h} \\
\text { or } 10 \mu \mathrm{g} / \mathrm{m}^{3} \text { per Year }\end{array}$ & $\frac{\mathrm{CO}}{10 \mathrm{mg} / \mathrm{m}^{3} \text { per } 8 \mathrm{~h}}$ & $\begin{array}{c}\mathrm{NO}_{2} \\
200 \mu \mathrm{g} / \mathrm{m}^{3} \text { per } 24 \mathrm{~h} \\
\text { or } 40 \mu \mathrm{g} / \mathrm{m}^{3} \text { per Year }\end{array}$ & $\begin{array}{c}\mathrm{SO}_{2} \\
20 \mu \mathrm{g} / \mathrm{m}^{3} \text { per } 24 \mathrm{~h}\end{array}$ & $\begin{array}{c}\mathrm{O}_{3} \\
100 \mu \mathrm{g} / \mathrm{m}^{3} \text { per } 8 \mathrm{~h}\end{array}$ \\
\hline Effects on human health & $\begin{array}{l}\text { - enter the nose, throat, } \\
\text { trachea, bronchus, } \\
\text { and bronchioles; } \\
\text { could cause airway } \\
\text { irritation, induce } \\
\text { oxidative stress } \\
\text { in the lungs, } \\
\text { and bronchial tubes, } \\
\text { and consequently, } \\
\text { could lead } \\
\text { to systemic } \\
\text { inflammation; } \\
\text { could also cause } \\
\text { bronchial remodeling } \\
\text { and even cancer after } \\
\text { chronic exposure }\end{array}$ & $\begin{array}{ll}- & \text { all symptoms } \\
\text { associated with } \mathrm{PM}_{10} \\
\text { exposure; } \\
\text { bronchial asthma, } \\
\text { allergic respiratory } \\
\text { diseases, and } \\
\text { increased mortality } \\
\text { in children; } \\
\text { increased blood } \\
\text { pressure in } \\
\text { hypertensive and /or } \\
\text { diabetic outdoor } \\
\text { workers. } \\
\text { Some authors claim } \\
\text { that this is one of the } \\
\text { most aggressive } \\
\text { pollutants for } \\
\text { humans, because } \\
\text { these particles could } \\
\text { enter the lung alveoli } \\
\text { and even the } \\
\text { bloodstream }\end{array}$ & $\begin{array}{l}\text { - enters the lung } \\
\text { alveoli and } \\
\text { bloodstream; } \\
\text { could bind to } \\
\text { hemoglobin, which } \\
\text { could cause vomiting, } \\
\text { nausea, and } \\
\text { dizziness; } \\
\text { new-born children } \\
\text { are the most } \\
\text { susceptible to these } \\
\text { problems }\end{array}$ & $\begin{array}{l}\text { - } \quad \text { enters the trachea, } \\
\text { bronchus, and } \\
\text { bronchioles; } \\
\text { is associated with } \\
\text { intense vehicle } \\
\text { traffic areas; } \\
\text { could cause asthma, } \\
\text { rhinitis, and other } \\
\text { conditions; } \\
\text { possesses irritating } \\
\text { potential and could } \\
\text { affect the mucosa of } \\
\text { the nose and throat, } \\
\text { which could cause } \\
\text { coughing and } \\
\text { allergies }\end{array}$ & $\begin{array}{l}\text { affects the upper } \\
\text { airways, trachea, } \\
\text { bronchi, } \\
\text { and bronchioles, } \\
\text { and could cause } \\
\text { allergic reactions, } \\
\text { bronchoconstriction, } \\
\text { changes in lung } \\
\text { function, and } \\
\text { respiratory } \\
\text { symptoms; } \\
\text { could cause irritation } \\
\text { of the mucosa of the } \\
\text { eyes, nose, throat, } \\
\text { and respiratory tract; } \\
\text { could cause coughing } \\
\text { and increased } \\
\text { bronchial reactivity, } \\
\text { facilitating } \\
\text { bronchoconstriction; } \\
\text { could affect the } \\
\text { thyroid }\end{array}$ & $\begin{array}{l}\text { - affects the trachea, } \\
\text { bronchus, } \\
\text { and bronchioles; } \\
\text { induces respiratory } \\
\text { inflammation, airway } \\
\text { obstruction, } \\
\text { coughing, } \\
\text { and discomfort; } \\
\text { has been associated } \\
\text { with increased } \\
\text { respiratory and } \\
\text { cardiovascular } \\
\text { problems, } \\
\text { particularly in the } \\
\text { elderly and children }\end{array}$ \\
\hline
\end{tabular}




\section{Materials and Methods}

\subsection{Questionnaire}

In this study, a survey was conducted from 2016 to 2018, and waste cooking oil was collected from the surveyed restaurants and residences in São Paulo city. A number of questionnaires were distributed in different regions of São Paulo city, according to the population and restaurant distributions [7,22,54-56]. Restaurant managers and residents were interviewed using a previously standardized and validated questionnaire. We intended to obtain answers to the following questions:

- Which region of São Paulo city are you located in?

- Do you use frying oil?

- How much frying oil do you use per month?

- What type of frying oil do you use?

- Do you reuse frying oil?

- How many times do you reuse frying oil?

- Are you aware of the environmental impact caused by improper frying oil disposal?

- Are you aware that frying oil could be used to produce biodiesel?

- What is the least expensive type of fuel?

- Would you be willing to store residual frying oil for free collection?

- Would you be willing to store for donate the residual frying oil?

- What type of company would you want to collect your residual frying oil from?

Currently, São Paulo city has 12.18 million inhabitants [57], an average of four individuals per residence (3.045 million residences), and 30,200 restaurants that use oil to prepare meals [58]. A total of 600 and 1500 questionnaires were distributed to restaurant owners and residents, respectively, in different regions of São Paulo city according to the population distribution (\%), and the return rate of the questionnaires answered by both residents and restaurant managers exceeded $98 \%$.

Table 2 illustrates the distribution of the questionnaires and the actual population distribution in São Paulo city. Data stratification was similar to the actual stratification of the population in São Paulo city, which ensured that the conclusions drawn would match the real population distribution. The surveys were distributed in a non-random manner to achieve the real stratification percentages; however, some surveys were not returned, and that contributed to the slight differences between the real and actual stratification.

Table 2. Distributions of population and survey participants in São Paulo city.

\begin{tabular}{cccc}
\hline City Area & Population (Million) & Distribution (\%) & Survey Participants (\%) \\
\hline Eastern & 3.6 & 33 & 32 \\
Southern & 3.1 & 28.5 & 26.3 \\
Western & 1.3 & 11.9 & 12.7 \\
Northern & 2.3 & 21.1 & 23.4 \\
Central & 0.6 & 5.5 & 5.6 \\
\hline Total & 10.9 & 100 & 100 \\
\hline
\end{tabular}

Source: SP City Hall [58].

Only one person was interviewed by residence or restaurant, with $2.5 \%$ error for residence and $4.0 \%$ error for restaurants at a $95 \%$ confidence level. The profile of the household interviewees was $58.40 \%$ female, $40.85 \%$ male, and $0.75 \%$ others; of these, $20.20 \%$ graduated college, $68.63 \%$ graduated high school, $8.87 \%$ only graduated elementary school, and the others did not report their education lever or were not literate. Despite the diversity of household respondents, all interviewed restaurant managers graduated college $[54-56,59,60]$. 


\subsection{Biodiesel Production}

Silva Filho et al. [15] used a mixture of oil and alcohol (volume ratio of 6:1 or molar ratio of 1:3.2) in a $3.0 \mathrm{~L}$ continuous stirred tank reactor. The reactions proceeded at $60{ }^{\circ} \mathrm{C}$ using $0.1 \% \mathrm{NaOH}(\mathrm{m} / \mathrm{v})$ as the catalyst, while the reaction mixture was constantly stirred for up to $120 \mathrm{~min}$. The amount of formed biodiesel was measured out every $10 \mathrm{~min}$ by decanting it into a separating funnel; the light phase was washed with petroleum ether and separated using a Soxhlet extractor.

The following properties of the obtained biodiesel were determined: The specific mass at $20{ }^{\circ} \mathrm{C}$ using the ASTM-D4052 method, the flash point using the ASTM-D93 method, the acid value using the Ca 5-40 method, and the moisture content using the Af 2-54 approach. These methods have been described, in detail, in the literature $[15,19,36]$. The biodiesel yield was calculated from the average molecular weight of oil. The formula used to calculate the biodiesel yield obtained from soybean oil $(835 \mathrm{~g} / \mathrm{mol})$ and ester $(881 \mathrm{~g} / \mathrm{mol})$ mixture $[15,19]$ could be written as follows:

$$
\text { Yield }(\%)=\frac{V_{\text {Biodiesel }} \times d_{\text {Biodiesel }} \times 835}{V_{\text {Oil }} \times d_{\text {Oil }} \times 835} \times 100
$$

where $V$ and $d$ are the volume and density, respectively, of waste cooking oil and biodiesel.

\subsection{Data Acquisition on Hospitalization and Gaseous Emissions}

The number of respiratory disease hospitalizations and their costs were collected using the TABNET-SUS-online platform. All data were selected the São Paulo city between 2009 and 2018 [29]. The number of monthly respiratory disease hospitalizations in São Paulo city hospitals and their costs were quantified and correlated with the pollutant emissions in the region during that period $[7,54,55]$.

Data on $\mathrm{PM}_{2.5}, \mathrm{PM}_{10}, \mathrm{O}_{3}, \mathrm{NO}_{2}, \mathrm{SO}_{2}$, and $\mathrm{CO}$ were collected in the neighborhoods of São Paulo city from 2009 until 2018 in accordance with the National Council of the Environment (CONAMA) standard [61]. Several sensors are placed in various regions of São Paulo city and constantly monitor the air quality, which are sent to a central agency of São Paulo State Environmental Company (CETESB) [62]. The monthly emitted air pollutants that presented the highest impact on residents' health were monitored using the relationships proposed by Arbex et al. [40] and Solé et al. [63], as cited by the WHO [10]. The research was conducted on the Qualar (air quality) page of the CETESB website (http:/ /ar.cetesb.sp.gov.br/padroes-de-quality-do-ar/ (accessed on 5 July 2020), and the monthly pollutant emissions data were filtered according to the metropolitan region (Alto Tietê) [61]. All available data were collected from official sources and represent $100 \%$ of the data available on the websites; however, $\mathrm{MP}_{2.5}$ monitoring started in 2010 [62]. Data on the rainfall index was collected over the last 30 years [62]. For comparison, the air quality standards presented by the WHO [61] and the air quality index proposed by the CETESB and available on the Qualar page [62] were used.

The following hypothesis was verified: The $\mathrm{PM}_{2.5}, \mathrm{PM}_{10}, \mathrm{O}_{3}, \mathrm{NO}_{2}, \mathrm{SO}_{2}$, and $\mathrm{CO}$ emitted by several air sources in São Paulo city contribute to the increased respiratory disease hospitalizations and their costs. Rain is known to decrease air pollution, and therefore, the effect of rainfall was also analyzed to determine whether it was correlated with the decrease in respiratory disease hospitalizations and their costs [40,43,63-66]. If an inverse relationship with the amount of rainfall could be confirmed, then the harmful effects of $\mathrm{PM}_{2.5}, \mathrm{PM}_{10}, \mathrm{O}_{3}, \mathrm{NO}_{2}, \mathrm{SO}_{2}$, and $\mathrm{CO}$ should increase in the absence of rainfall [16-18,21]. To verify if there is an effect of each gas parameter on hospitalization, Pearson's correlation was used. The Pearson correlation coefficient was used to perform statistical analysis of the data, and their values were classified as strong, moderate, and weak correlation $[10,54,55]$. 


\subsection{Environmental Cost Accounting Strategies}

The cost of biodiesel produced from residual frying oils was determined according to the assumptions of Oliveira Neto et al. [4]; Miranda et al. [19], and Silva Filho et al. [15] as follows:

(a) the population was considered to comprise the number of restaurants $(30,200)$ and households (3.045 million), according to their respective representative sectors [54,55];

(b) the monthly average amount of waste cooking oil was considered the one reported into questionnaires from surveys for the household and restaurant populations, considering their respective weights;

(c) the monthly average amount of waste cooking oil $\left(V_{W F O}\right)$ to be collected monthly was calculated using Equation (2):

$$
V_{\mathrm{WFO}}(\mathrm{L})=\frac{N_{1}}{n_{1}} \times \sum_{j=1}^{n_{1}} x_{j}+\frac{N_{2}}{n_{2}} \times \sum_{k=1}^{n_{2}} x_{k}
$$

where $N$ and $n$ are the population and sampling, respectively, and $j$ and $k$ denote households and restaurants, respectively;

(d) the waste cooking oil would be collected by attaching a reservoir to the garbage collection trucks for this specific purpose;

(e) the net value of the logistics planning and waste oil collection cost would be zero;

(f) the waste cooking oil would be donated by the population and restaurants to the City Hall;

(g) conversely, homes and restaurants should not be charged for collecting the waste frying oil, and thus, the net cost of biodiesel for the population and City Hall would also be zero;

(h) the amount of biodiesel obtained would be determined by the monthly volume of collected waste frying oil, multiplied by the yield of the biodiesel production reaction as follows:

$$
V_{\text {Biodiesel }}(\mathrm{L})=V_{\text {Oil }}(\mathrm{L}) \times \text { Yield }
$$

(i) the price of traded biodiesel would be used to calculate the profit from its sales as follows:

$$
\left(\operatorname{Profit}_{\text {Biodiesel }}(\mathrm{L})=V_{\text {Biodiesel }}(\mathrm{L}) \times \operatorname{Price}(\mathrm{US} \$ / \mathrm{L})\right.
$$

(j) biodiesel production would be associated with carbon credits, and 2.5 carbon credits would be attributed per ton of biodiesel. These carbon credits would also contribute to the biodiesel production profits and improve the image of São Paulo city.

This conversion of the energy consumed (or surplus of energy) to carbon credits would be performed using the Official Carbon Credits Calculator developed by the Brazilian GHG Protocol certified by the LRQA Business Assurance [15].

The use of biodiesel would enable the reduction of $\mathrm{CO}_{2}$ emissions and would consequently translate into 2.5 carbon credits for each ton of $\mathrm{CO}_{2}$; the biodiesel carbon credits would be calculated using Equation (5) [15,19]:

$$
\mathrm{CC}_{\text {Biodiesel }}\left(\text { ton } \mathrm{CO}_{2}\right)=2.5 \times m_{\text {Biodiesel }}
$$

where $m_{\text {Biodiesel }}$ is the mass of biodiesel obtained using Equation (6) $[12,15]$.

$$
m_{\text {Biodiesel }}(\text { ton })=V_{\text {Biodiesel }} \times d_{\text {Biodiesel }}
$$

where $V_{\text {Biodiesel }}$ and $d_{\text {Biodiesel }}$ are the volume and density of biodiesel, respectively.

The profit associated with the sale of the carbon credits could be obtained using Equation (5) [15], as follows:

$$
\text { CC Profit }(\mathrm{US} \$)=\text { tonCO } \mathrm{C}_{2} \times \text { Current Price }(\mathrm{US} \$ / \text { tonCO } 2)
$$


(k) the profit from the glycerine generated as by-product would also be accounted for. The mass of glycerine ( $\left.m_{\text {Glycerine }}\right)$ would be calculated from $m_{\text {Biodiesel }}$ using its stoichiometric ratio to biodiesel, according to Equation (8), and its profit would be determined using Equation (9):

$$
m_{\text {Glycerine }}(\mathrm{kg})=\frac{92}{881} \times m_{\text {Biodiesel }}(\mathrm{kg})
$$

and

$$
\text { Profit }_{\text {Glycerine }}=m_{\text {Glycerine }}(\mathrm{kg}) \times 5.7(\mathrm{US} \$ / \mathrm{kg})
$$

(1) the replacement of fossil fuels with biodiesel would reduce the emission of pollutants and respiratory disease hospitalizations by 30\% [10]. Thus, it was considered that switching from diesel oil to biodiesel would also reduce the hospitalization-related cost by $30 \%$, and that was considered in the final accounting. Consequently, the decrease in hospitalization cost was calculated as follows:

$$
\text { Hospitalisation savings (US\$) }=0.30 \times \text { Total hospitalisation cost (US\$) }
$$

All fuel prices and hospitalization costs cited in the paper were retrieved from their original sources (ANP, SUS, base year 2019) and were converted to US \$ to avoid fluctuations or the effects of inflation during the period following data collection and interpretation. The price of glycerine and carbon credit followed the values traded by the European Union $[4,5,15,19]$.

Subsequently, the environmental cost accounting was summarized, and the data were presented in a table. The data presented the positions and evolutions of São Paulo city as it adopted the ecologically friendly system proposed in this study.

The steps of the eco-friendly process for discarding waste cooking oil are presented below $[15,19]$ :

Stage 1-the current unsustainable stage. At this stage, the environmental effects are associated with the processing of the feedstock and production of waste, and do not include the production costs.

Stage 2-a more sustainable stage in which the company is taking steps to reduce its effect on the environment.

Stage 3-the stage in which operations should not affect the environment.

Stage 4-the stage in which the company is self-sustainable, whereby the environmental accounting balance of its operations generates credits for the company.

\section{Results and Discussion}

\subsection{Effects of Polluting Gases on Human Health and Healthcare Costs}

Figure 1 depicts the annual variations in the $\mathrm{PM}_{2.5}, \mathrm{PM}_{10}$, and $\mathrm{NO}_{2}$ emissions in São Paulo city during the study period. These gases were the ones that were mostly outside the standards established by the WHO, in the period studied. Since the beginning of the environmental monitoring period, the emissions have exceeded the limit set by the WHO. Although the emissions decreased in 2018, the emission values still exceeded the annual WHO-established standards for air quality. Thus, the residents of São Paulo city are more prone to developing respiratory health problems owing to their prolonged exposure to these pollutants, and it is possible that some residents might have acquired chronic diseases or cancer or might have even prematurely died. At the end of 2017, there was a change in the positions of the data collection stations, and this may have influenced the reduction of emissions in the following year. 


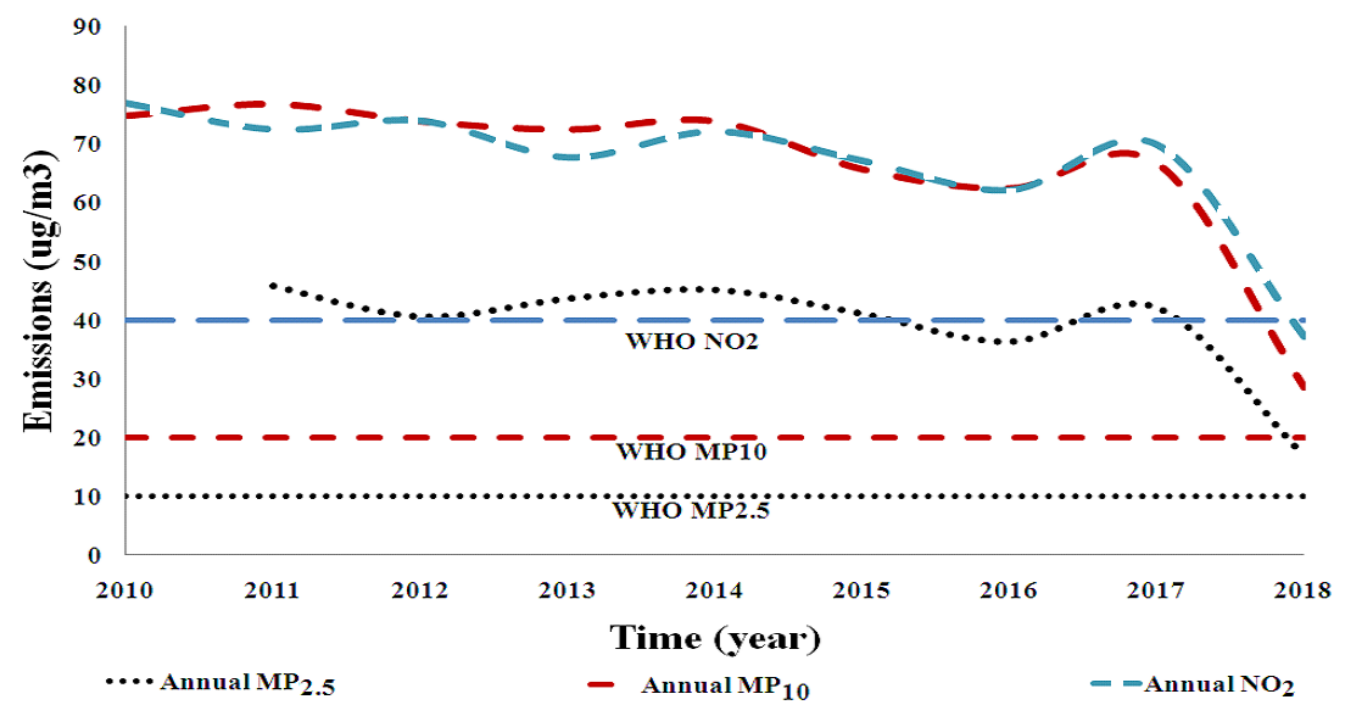

Figure 1. Annual $\mathrm{PM}_{2.5}, \mathrm{PM}_{10}$, and $\mathrm{NO}_{2}$ emissions during the study period.

During the study period, $I_{\mathrm{AQ}}$ was determined using Equation (2) and the results are presented in Figure 2. The monthly averages, and their lower and upper limits, are represented on the curve. Air quality was poor throughout the study period, even when the recorded levels were very low. Moreover, $I_{\mathrm{AQ}}$ was moderately correlated with respiratory disease hospitalizations and their costs. This indicated that all polluting gases affected the number of hospitalizations and their costs $[35,59,67,68]$, and that those exposed to these pollutant gases could develop any of the conditions listed in Table 1 owing to a combined intoxication effect [34,65]. Of all pollutants, $\mathrm{PM}_{2.5}$ was responsible for $65.8 \%$ of the total number of poor air quality-related hospitalizations, followed by $\mathrm{PM}_{10}(29.6 \%)$ and $\mathrm{O}_{3}(4.6 \%)$, and these data agreed with the results summarized in Table 3.

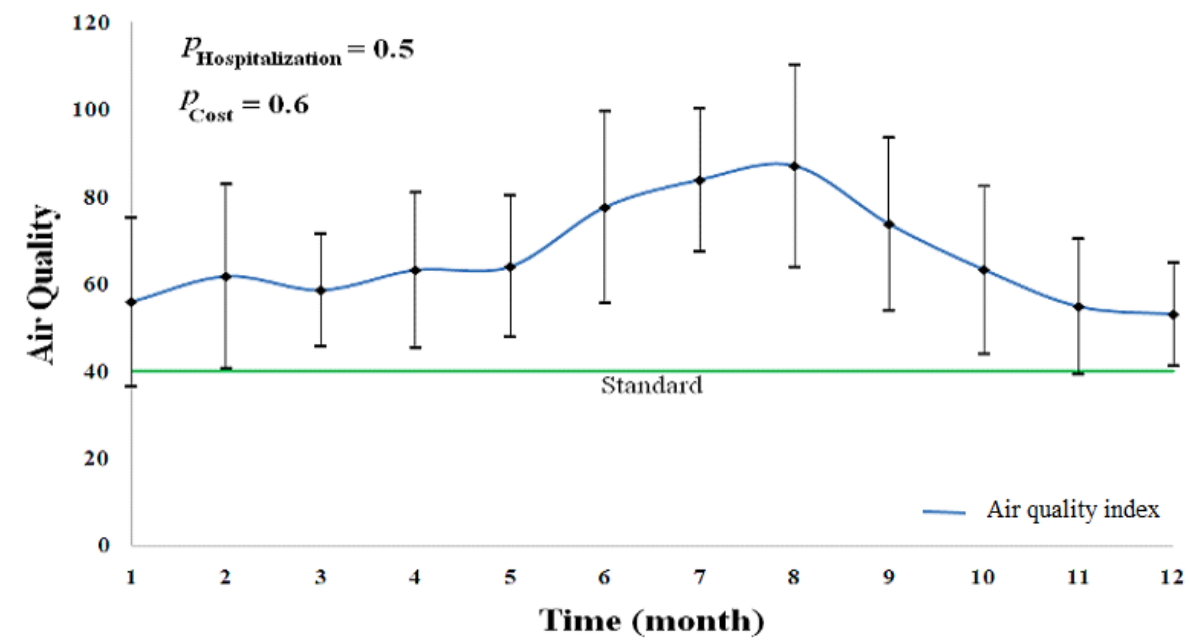

Figure 2. Monthly air quality behavior in São Paulo during the period studied. 
Table 3. Average monthly emissions, hospitalizations, and their costs during the study period (2009-2018).

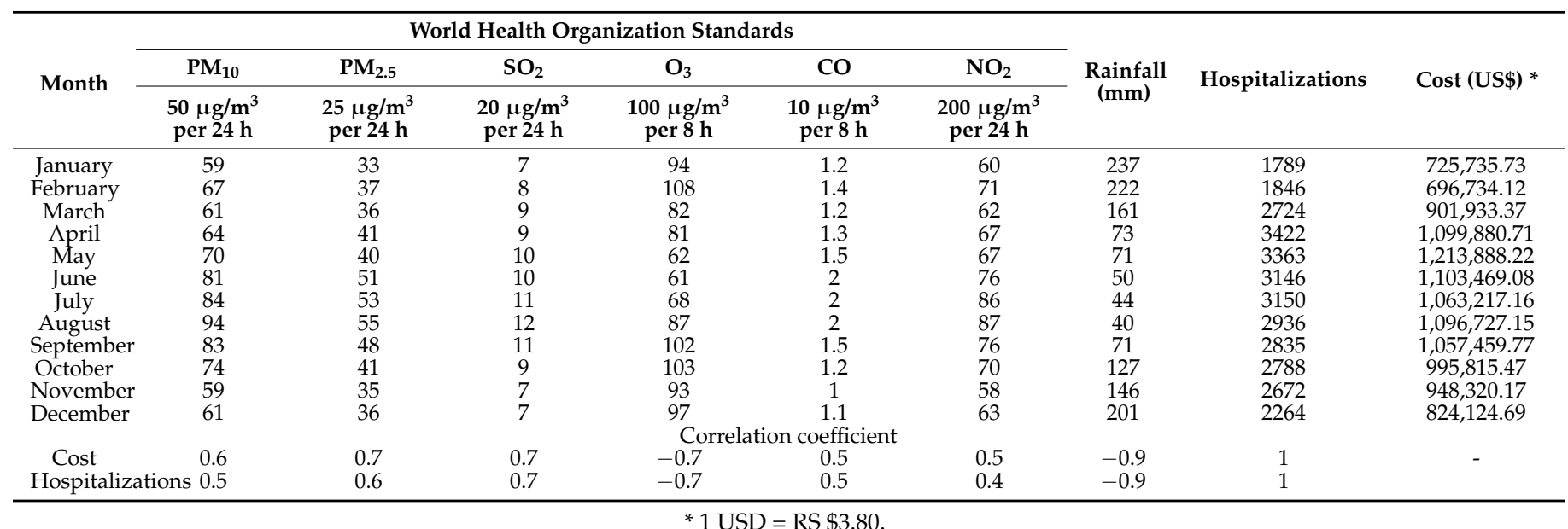

These pollutants could affect the nose, throat, trachea, bronchus, and bronchioles; they could cause airway irritation and obstruction, coughing, and discomfort, could induce oxidative stress in the lungs and bronchial tubes, and consequently, could lead to systemic inflammation. Moreover, chronic exposure could cause bronchial remodeling and even cancer. In addition, $\mathrm{PM}_{2.5}$ could cause bronchial asthma, allergic respiratory diseases, increase mortality in children, and increase blood pressure in hypertensive and/or diabetic outdoor workers. Furthermore, $\mathrm{O}_{3}$ could cause cardiovascular problems, particularly in the elderly and children; however, $\mathrm{PM}_{2.5}$ is considered to be the most damaging pollutant to human health [61].

The worst IQA values are observed in August, and this reflects an increase in hospitalizations in the following month, as according to Natali et al. [69], in September there is a peak of hospitalizations for respiratory diseases in São Paulo.

Table 3 summarizes the average monthly emissions, hospitalizations, and their costs during the study period. The emission values represent the monthly averages from 2010 until 2018, and the rainfall values, hospitalizations, and their costs are the monthly averages over 10 years (from 2009 until 2018). No emission data were available before 2009. The overall average monthly number of hospitalizations was 2744 , and the average individual hospitalizations cost was approximately US $\$ 356.10$ per patient. During the study period (2009-2018), 329,329 respiratory disease hospitalizations were recorded in the SUS database, which amounted to US $\$ 117.273$ million. Both the number of hospitalizations and their costs decreased as the amount of rainfall increased, probably owing to the rainfall improving air quality, as reported by Locosseli et al. [64], Sera et al. [65] and Zhao et al. [66]. According to Duhanyan and Roustan [70], Xu et al. [71] and Zhao et al. [63], the pollutants, gases, and PM are removed from air by below-cloud wet scavenging and precipitating inside the raindrops.

Throughout the study period, the emission rates of $\mathrm{PM}_{10}$ and $\mathrm{PM}_{2.5}$ were higher than the WHO-established values, when the maximum tolerable must not exceed three times a year. This indicated that the air quality in São Paulo city was poor throughout the study period. Consequently, the population is at risk of developing health problems owing to their exposure to the air pollutants. Thus, the longer the exposure to air pollutants, the greater the damage to human health $[17,66] . \mathrm{O}_{3}$ was another pollutant that exceeded the WHO-set limits on some occasions, while the amounts of the other pollutants were always below the WHO-established limits.

Most emissions were positively correlated with the number of hospitalizations and their costs; moreover, the correlations of the pollutants were either moderate or strong. This demonstrated that such pollutant gases affected the number of respiratory disease hospitalizations, which corroborated the information reported by $[17,31,65,66]$. The amount of rainfall was inversely proportional to the number of respiratory disease hospitalizations, 
which was expected, because rainfall precipitates some pollutants and could improve air quality. However, the amount of $\mathrm{O}_{3}$ was also inversely proportional to the number of respiratory disease hospitalizations, which differed from the data reported by most scholars. Nonetheless, this did not indicate that $\mathrm{O}_{3}$ did not affect air quality, as its concentration exceeded the WHO recommendations [10] for some months of almost every year of the study period.

Therefore, the relationship between the emissions and hospitalizations, that was reported for several cities worldwide, has also been documented for São Paulo city. Thus, according to the $\mathrm{WHO}$ [10], reducing the emissions could reduce the respiratory disease hospitalizations costs by at least $30 \%$. If the policy of replacing diesel oil with biodiesel were adopted, São Paulo city could reduce the number of annual respiratory disease hospitalizations by approximately 98,800 . Consequently, that could save approximately US $\$ 35$ million over a 10 years period or US \$3,518,191.69 annually.

Although it advocates replacing diesel oil with biodiesel, it must not forget that biodiesel also releases NOx and ultrafine particles, and those could still cause respiratory diseases [28,46,72]. However, biodiesel emissions are less harmful than the diesel oil ones and could reduce the respiratory disease hospitalizations their costs by at least $30 \%$ (would be $100 \%$ if not polluted); moreover, according to the WHO [10], biodiesel a renewable source [7].

\subsection{Outcome Drawn from the Survey Data}

Figure 3 illustrates the degree of agreement to the questions that addressed the usage, environmental impact, and amount of frying oil used. Figure $4 a, b$ presents the average respondent replies for households and restaurants in São Paulo city, respectively. As noted, $96 \%$ and $100 \%$ of the households and restaurants interviewed, respectively, reported that they use edible oils to fry foods, and $70 \%$ of both categories of interviewees indicated reusing the frying oils.
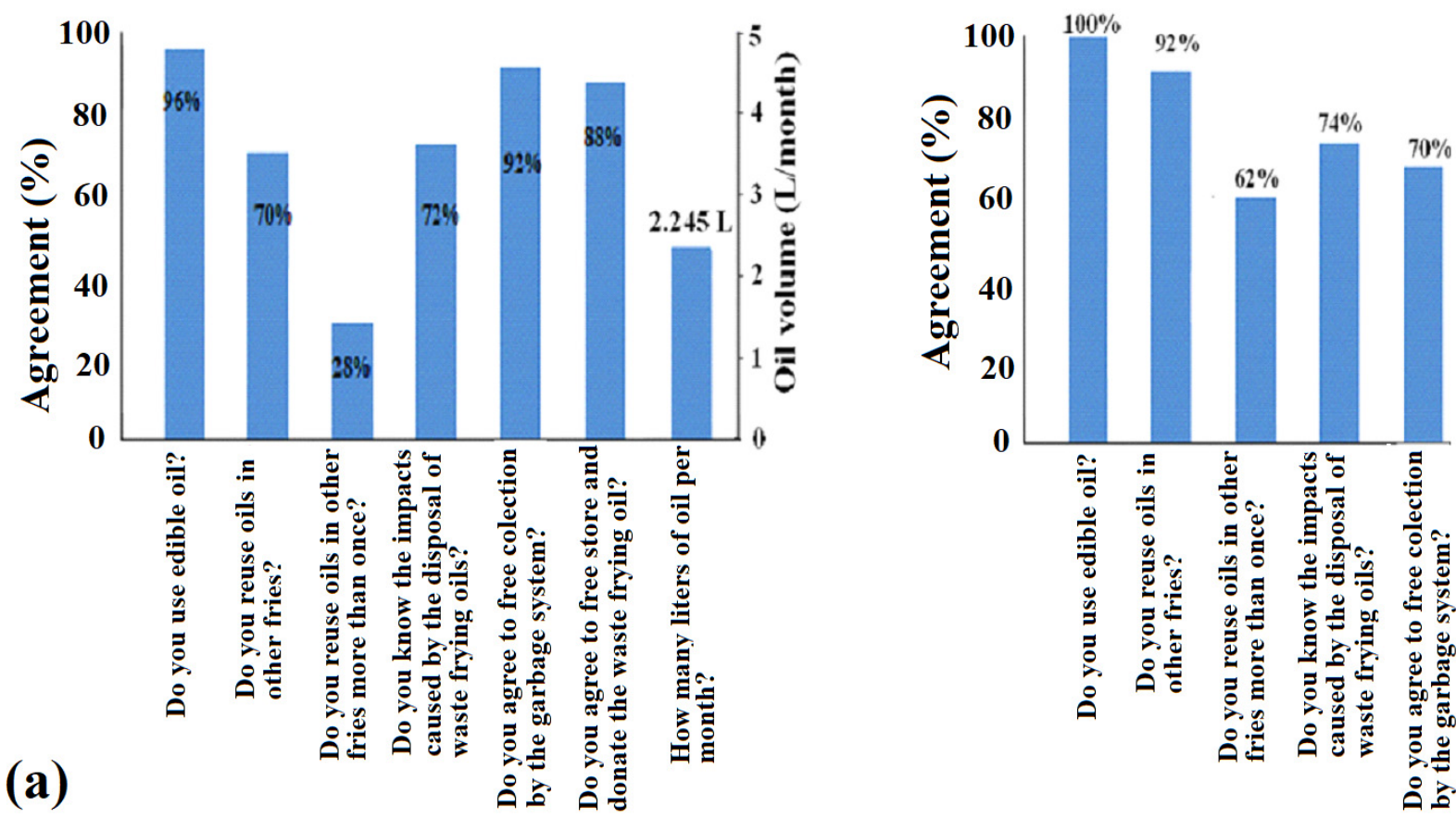

Figure 3. Answers to survey questions that addressed the usage, environmental impact, and amount of waste frying oil: (a) Households and (b) restaurants. 

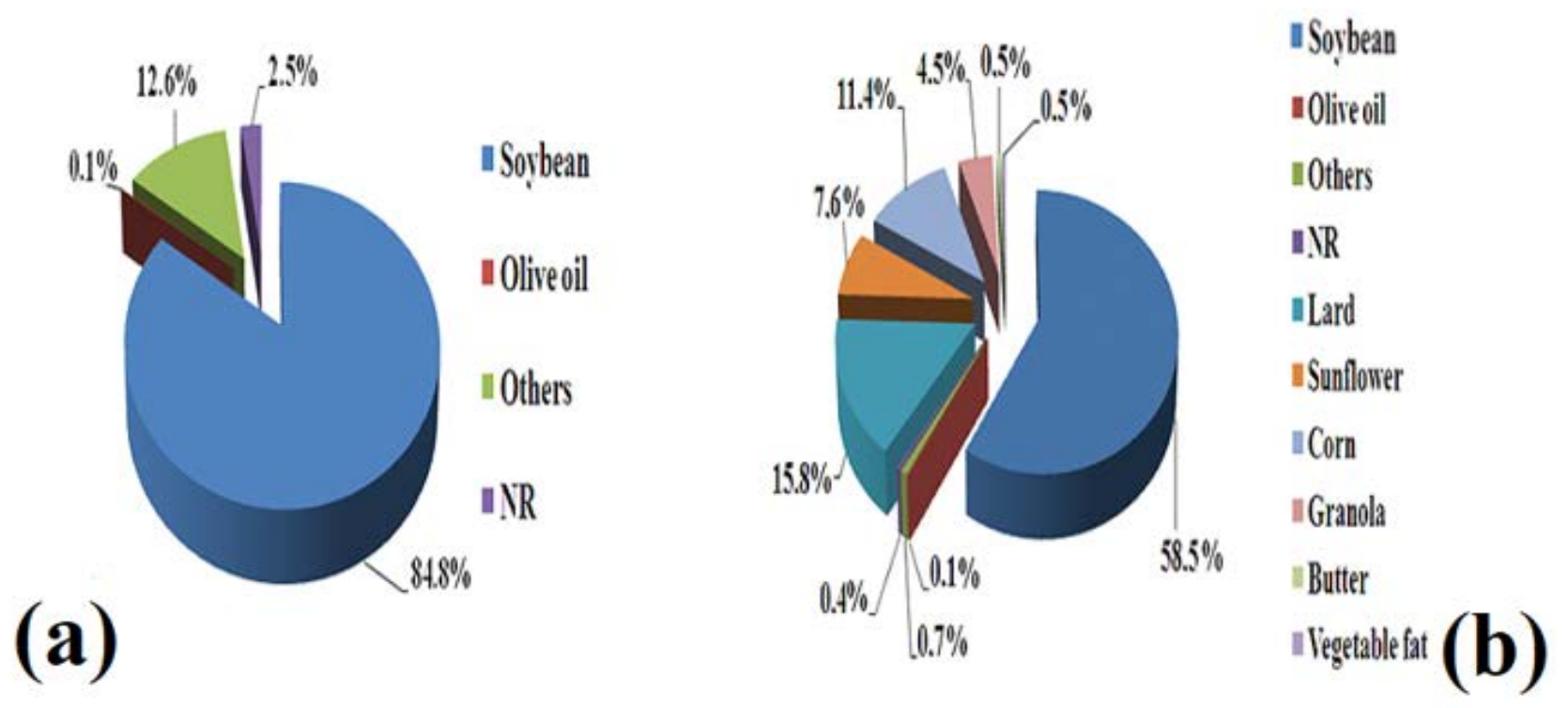

Figure 4. Survey data on types of oils used for frying: (a) Households and (b) restaurants.

For the household interviewees, $70 \%$ of all respondents reported reusing the oils, and less than $30 \%$ mentioned reusing the same oil at least twice. For the restaurants, $92 \%$ of all respondents indicated that they reused the oils, and $62 \%$ reused the same oil at least twice. Giraçol et al. [73] reported that the constant reuse of edible oils for various fried foods, exposes the oils to high temperatures for long periods, which causes their oxidation and the release of free radicals, which are subsequently ingested, and consequently, could damage the health of those who consume those foods. Therefore, reusing these edible oils for frying should be avoided.

The percentages of interviewed households and restaurants that were aware of the environmental effects of the irregular disposal of waste frying oils were $72 \%$ and $74 \%$, respectively. The most cited environmental effects were: Soil contamination, water pollution, and sewage clogging.

Moreover, the environmental awareness of household respondents was higher than that of the restaurant managers. Approximately $90 \%$ of households and only $70 \%$ of restaurant managers agreed with the proposal to store and donate for free collect waste frying oils. This demonstrated that the population would be willing to contribute and implement environmentally correct procedures for the disposal and storage of waste frying oils. The average monthly amounts of waste frying oils used in households and restaurants, were 2.245 and $97.663 \mathrm{~L}$, respectively. Therefore, the overall monthly average amount of residual frying oil was determined to be $9794.6 \mathrm{~m}^{3}$, of which $69.89 \%$ was contributed by households.

Figure $4 \mathrm{a}, \mathrm{b}$ presents the percentages of the different types of waste cooking oil used in households and restaurants, respectively, which were compiled after the survey answers were analyzed. Our study indicated that soybean oil was the most commonly used for frying, owing to its low cost, compared to those of other oils, and accounted for $84.8 \%$ and $58.4 \%$ of the amount of frying oils used in households and restaurants, respectively. The percentage of olive oil used for frying in both households and restaurants was $0.1 \%$, probably because olive oil is typically used as a salad dressing. The types of oils used in restaurants were more diverse and included lard $(15.8 \%)$, corn oil $(11.4 \%)$, and sunflower oil $(7.6 \%)$.

The average composition of the waste cooking oil in São Paulo city was determined using the contributions of the households and restaurants, and the results are presented in Figure 5. Soybean oil accounted for approximately $80 \%$ of the entire amount of waste cooking oil, and lard, corn, sunflower, and granola oils accounted for $12 \%$. These results were very useful for studying the reaction kinetics and finding the best conditions to pro- 
duce biodiesel from the waste cooking oil collected in São Paulo city. A survey conducted in restaurants in São José do Rio Preto, São Paulo, Brazil, revealed that soybean oil represented $86.2 \%$ of the edible oil used for food preparation [74]. Another survey conducted in restaurants located in cities on the coast of São Paulo indicated that soybean oil accounted for $76 \%$ of the edible oils used for food preparation, and the other used oils were lard and vegetable fat [75].
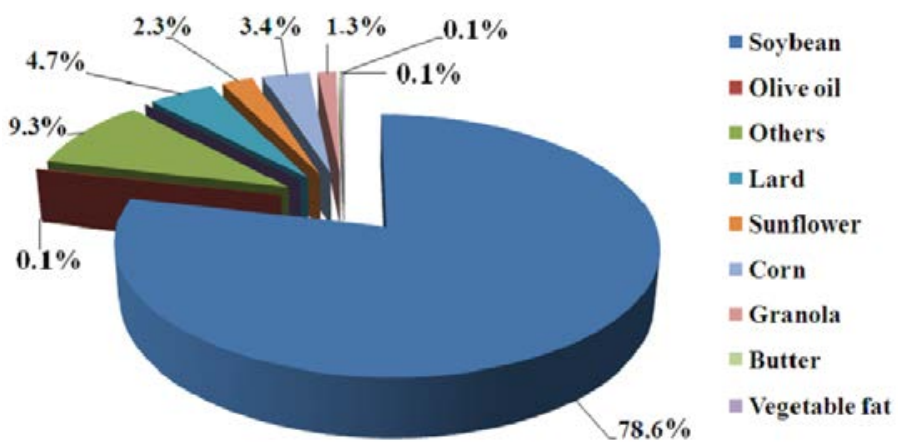

Figure 5. The average composition of waste cooking oil in São Paulo city.

Figure $6 \mathrm{a}, \mathrm{b}$ illustrates the disposal of waste frying oils from households and restaurants, respectively. Only $26 \%$ of households had access to selective collection facilities for their waste frying oils (Figure $6 \mathrm{a}$ ). In addition, $35 \%$ of the interviewed restaurant owners stated that they had access to selective collection facilities (Figure 6b). Moreover, significant percentages of the household (52.1\%) and restaurant $(56 \%)$ survey respondents reported discarding waste cooking oil using unregulated methods (pouring it in sinks, sewers, or drains, throwing it away in garbage bags, or disposing of it in yards). However, the percentage of restaurant managers who graduated college was five times higher than the corresponding percentage of household respondents; therefore, it was expected that restaurant managers would be more environmentally aware than the other survey participants. This indicated that environmental awareness was not directly related to the education level of people in São Paulo city. Incorrect disposal of waste frying oils could contaminate rivers, soils, cause significant disruption in the food chain, and affect aquatic life, and therefore, could negatively affect natural resources. Thus, it could be concluded that no public policy currently encourages the correct collection of waste cooking oil in São Paulo city.

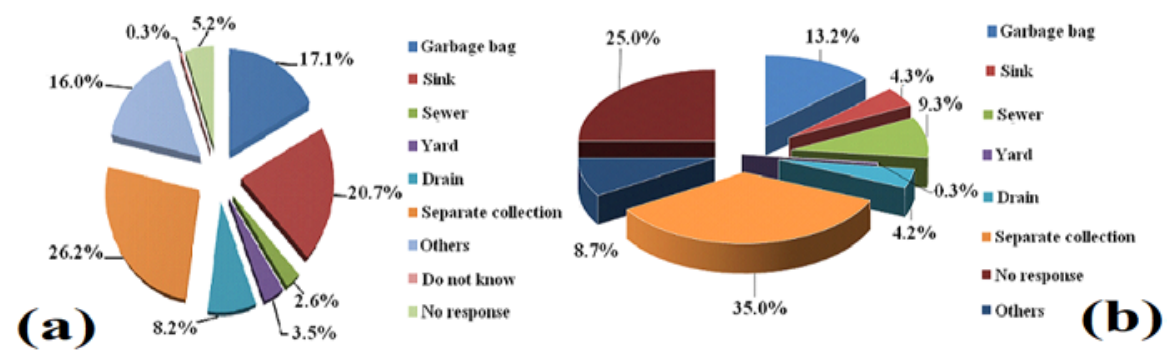

Figure 6. Waste cooking oil disposal survey answers: (a) Households and (b) restaurants.

A study conducted in Goiânia, Brazil, revealed that households discarded $40 \%$ of waste frying oils by throwing them away in garbage bags and $20 \%$ by pouring them down the sink drain, i.e., $60 \%$ of the population irregularly discarded this residue [76]. When interviewing residents in Duque de Caxias, Brazil, it was concluded that $66 \%$ of the waste cooking oil was irregularly discarded; indicating an amount similar to that found in São Paulo [77].

Castro et al. [78] determined that $43 \%$ of the frying oils used in restaurants in Mogi das Cruzes, Brazil were selectively collected and were used for soap making, which indicated 
that the restaurant managers in the area were more environmentally aware than those in São Paulo. However, most waste frying oils were discarded irregularly using the same methods mentioned above, and therefore, caused the same environmental effects as those in São Paulo city. We concluded that Brazilian residents were not aware of any policy on the correct disposal of waste frying oil. Therefore, strategies to increase the environmental awareness, campaigns, and incentives for the selective collection of waste frying oils should be urgently implemented to minimize the damage caused by the incorrect discharge of waste frying oils.

Figure 7 illustrates the perception of the survey participants on the type of company that should collect waste oil. Approximately $57 \%$ and $45 \%$ of the household and restaurant interviewees, respectively, indicated that they would prefer that the waste cooking oil be collected by public or third-party companies. Moreover, $25-30 \%$ of respondents indicated that waste frying oils could be collected by any company, and therefore, expressed no objections to a public or third-party company collecting it. This indicated that approximately $80 \%$ of the interviewees would agree that the waste frying oils should be collected by a public company or a partner third party company.

(a)

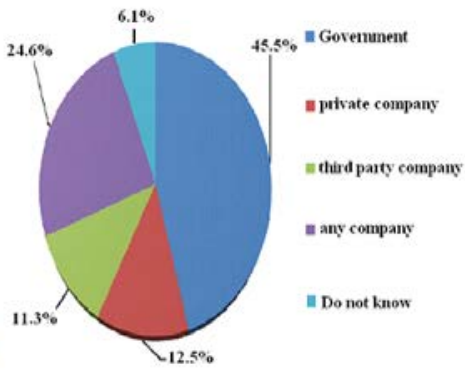

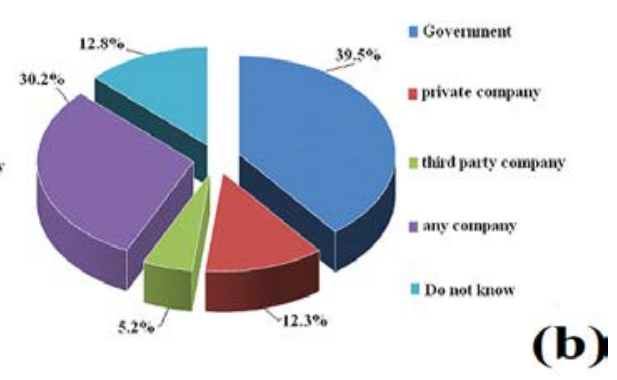

Figure 7. Types of companies that interviewees considered that should collect waste frying oils: (a) Households and (b) restaurants.

A study conducted in Ponta Grossa, Brazil indicated that 98\% of the interviewed restaurant managers agreed to the selective waste cooking oil collection by a public company, and $96 \%$ of them agreed to donate the waste frying oils [79].

Figure 8a,b depicts the variations in the degree of agreement on the biodiesel questions in the survey between household and restaurant participants, respectively. The survey data revealed that $70 \%$ and $62 \%$ of the household and restaurant respondents, respectively, believe that producing biodiesel from soybean oil could increase the supermarket price of edible oils. Approximately $66 \%$ and $36 \%$ of the household and restaurant respondents, respectively, indicated being aware of the possibility of producing biodiesel from waste frying oils. This demonstrated that household respondents were more environmentally aware than restaurant managers. Furthermore, $72 \%$ of both the household and restaurant survey participants were aware that biodiesel could be used as fuel in cars, buses, and trucks. When answering the open-ended survey questions, both categories of interviewees indicated that biodiesel could be used as fuel for trucks, buses, bucket trucks, power generators, agricultural and industrial engines. Moreover, both types of respondents believed that biodiesel could replace other fuels, the company responsible for producing biodiesel would be profitable, and that bus tickets could be more affordable if biodiesel were used as fuel for public transportation buses. This demonstrated that both categories of survey participants shared similar ideas about biodiesel. 


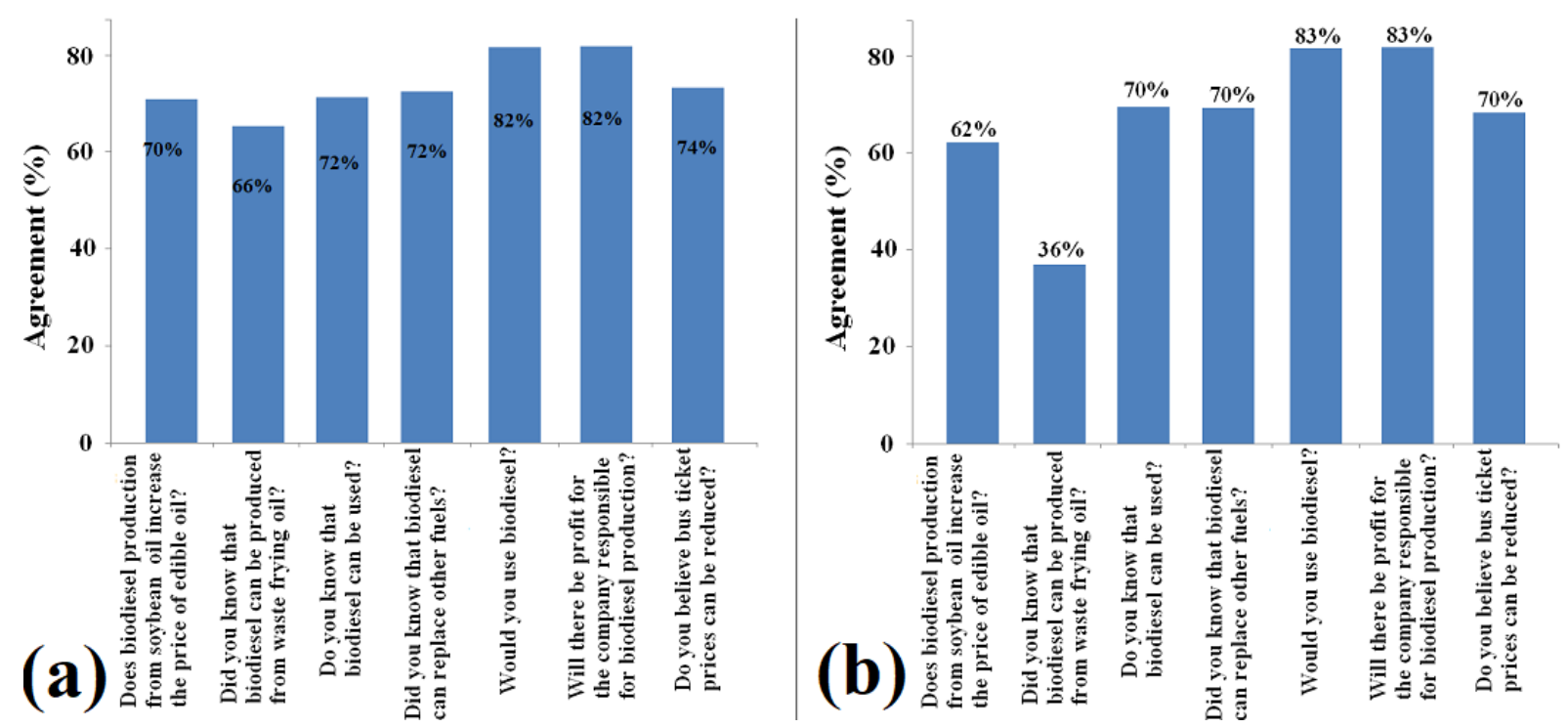

Figure 8. Answers to questions on the use of biodiesel: (a) Households and (b) restaurants.

Thus, it was observed that interviewees intended to act collaboratively towards the storage and collection of residual frying oil, and supported the production of biodiesel mainly by public companies. Therefore, it would be up to the government to elaborate a policy that would inform the population on the correct methods for the disposal and collection of these residues, and to institute awareness campaigns that would promote incentives for the spontaneous and widespread collection of waste frying oils [70].

According to the results presented in Figure 7, a company managed by the São Paulo City Hall would have to collect the waste frying oils. The collection logistics should be the same as that for the collection of garbage, and would simply require the addition of an oil-collection tank to garbage collection trucks, as suggested by Miranda et al. [16] in Campinas and Guarulhos, São Paulo, Brazil. Figure 9 presents photographs of samples collected during the distribution and collection of the surveys that were subsequently used to produce biodiesel. The samples were stored in a laboratory in a temperature range of $15-25^{\circ} \mathrm{C}$. The restaurant waste cooking oil samples were cloudy and included white deposits that comprised flour and fat. The households waste cooking oil samples were cloudy only at low temperatures and clear at $25^{\circ} \mathrm{C}$, and also included small deposits that consisted of flour, meat, and other food residues. The mixture of waste frying oils was cloudy at $15{ }^{\circ} \mathrm{C}$ and included a small flour and fat deposit; moreover, at $25^{\circ} \mathrm{C}$ the mixture was clear, and its fat and flour deposits were smaller than at $15^{\circ} \mathrm{C}$. Therefore, Figure 10 reveals that oil collection on cold days could be challenging, as the fat and flour residues could hamper the flow, particularly for the waste oils collected from restaurants.

To render this waste oil collection proposal viable, logistic actions are essential, as no specific Federal Law on the disposal of cooking oil exists. Therefore, the proper disposal or recycling of cooking oils by establishments and/or the citizens themselves could be challenging, and therefore, it would be necessary to create concrete conditions that would prevent the discarding of oils into the wild, encourage recycling, and supervise the disposal establishments. Furthermore, tailored vehicles (municipal garbage trucks with collectors) would have to be equipped with appropriate oil collection and transportation containers. 


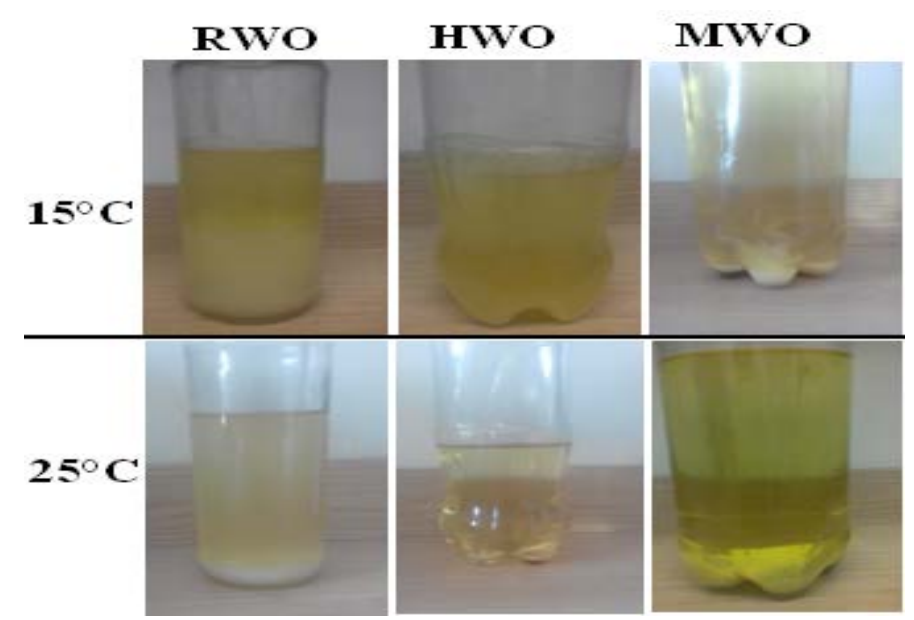

Figure 9. Waste cooking oil samples collected from households and restaurants.

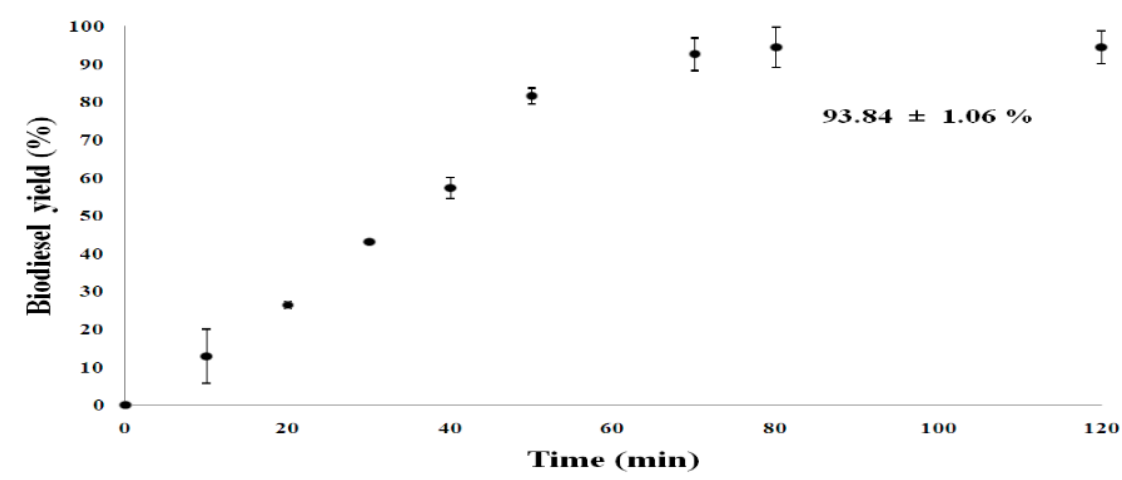

Figure 10. Biodiesel formation curve from the restaurant and residential waste cooking oil mixture.

\subsection{Environmental Cost Accounting Analysis}

The total monthly waste cooking oil production of $9794.6 \mathrm{~m}^{3}$ was estimated using the current population of São Paulo city and the average monthly quantities of waste cooking oil reported by restaurants and households (97.663 and $2.245 \mathrm{~L}$, respectively). Table 4 presents the biodiesel quality assessment data based on the mixture of restaurant and households waste oils. All physicochemical properties of the obtained biodiesel were within the National Agency of Petroleum [36] standards. Figure 10 shows the kinetic curve for obtaining biodiesel, which had an average biodiesel yield was $93.84 \%$, and the purity of the obtained biodiesel samples was $98.41 \pm 0.28 \%$ (the minimum purity should be $96.5 \%$ ). Thus, $9191.2 \mathrm{~m}^{3}$ (7990.4 t) biodiesel could be produced every month from the total amount of waste cooking oil used collected from restaurants and households in São Paulo city.

Table 4. Properties of biodiesel obtained from waste cooking oil mixture.

\begin{tabular}{ccccccc}
\hline Source & Yield (\%) & Density $(\mathbf{g} / \mathbf{m L})$ & $\begin{array}{c}\text { Acid Value } \\
(\mathbf{g} / \mathbf{1 0 0} \mathbf{~ g})\end{array}$ & $\begin{array}{c}\text { Moisture } \\
(\mathbf{g} / \mathbf{1 0 0} \mathbf{g})\end{array}$ & $\begin{array}{c}\text { Flash Point } \\
\left({ }^{\circ} \mathbf{C}\right)\end{array}$ & $\begin{array}{c}\text { Viscosity } \\
(\mathbf{m m} / \mathbf{s})\end{array}$ \\
\hline Biodiesel & $93.84 \pm 1.06$ & $0.8834 \pm 0.0251$ & $0.3627 \pm 0.2517$ & $0.023 \pm 0.002$ & $51.0 \pm 0.4$ & $4.0 \pm 0.5$ \\
\hline ANP & - & $0.875-0.900$ & $<0.8$ & $<0.5$ & $>38$ & $3.0-6.0$ \\
\hline
\end{tabular}

According to the São Paulo City Hall [56] data, the city fleet comprises approximately 15,000 diesel vehicles (buses, tractors, trucks, pickup trucks, and others), and it consumes $33,333 \mathrm{~m}^{3}$ diesel oil monthly, which translates into the monthly fuel cost of US $\$ 18,392,982.46$. This fuel cost was used to evaluate the economic efficiency of the proposal 
in this study. Thus, the biodiesel obtained by São Paulo is equivalent to $27.57 \%$ of the total needed, and thus, the remaining value for $100 \%$ biodiesel will continue to be purchased.

The proposal involves a biodiesel production plant, and a proposed cash flow that includes the acquisition of fuels and production of biodiesel for such a plant is presented in Table 5. It was assumed that the waste cooking oil was donated by the São Paulo residents; therefore, no cost was associated with it. Moreover, the transportation cost was not included because the waste oil was collected at the same time garbage was collected.

Table 5. Current monthly balance of capital outflow.

\begin{tabular}{cccc}
\hline Description & $\begin{array}{c}\text { Quantity } \\
\text { (Unit/Month) }\end{array}$ & Price (US\$) & $\begin{array}{c}\text { Unit Cost } \\
\text { (US\$/Month) }\end{array}$ \\
\hline Biodiesel plant & $1 / 120^{*}$ & $1,000,000.00$ & 8333.33 \\
\hline Maintenance (\%) & 4.00 & 8333.33 & 333.33 \\
\hline Oil fuel (L) & $33,333,333.33$ & 0.9511 & $31,703,333.34$ \\
\hline Ethanol (L) & $1,001,299$ & 0.5047 & $505,392.43$ \\
\hline & Monthly total cost (US\$) & $32,217,392.44$ \\
\hline & Annual total cost (US\$) & $386,608,709.25$ \\
\hline
\end{tabular}

* is the useful life of the plant $=10$ years or 120 months.

For this volume of biodiesel, a biodiesel production plant with an output of $14 \mathrm{~m}^{3} / \mathrm{h}$ would be sufficient. The market start-up price of a similar plant is US \$1 million (Mercado Livre, 2019). Given that the service life of the equipment was 10 years, and the $4 \%$ maintenance cost was added to the proposal, the monthly and annual costs of US $\$ 8,666.66$ and 104,000, respectively, were determined.

Two profit scenarios are presented below, and for both scenarios it was assumed that the oil would be donated:

Scenario 1: The sale of all products generated during the fabrication of biodiesel and its inflow balance is summarized in Table 6.

Table 6. Monthly balance of capital inflow for scenario 1.

\begin{tabular}{cccc}
\hline Description & $\begin{array}{c}\text { Quantity } \\
\text { (Unit/Month) }\end{array}$ & Price (US\$) & Profit (US\$/Month) \\
\hline Biodiesel (L) & $9,191,236.31$ & 0.7518 & $6,910,358.46$ \\
\hline Carbon Credit (t CO 2$)$ & $19,976.09$ & 9.25 & $184,778.90$ \\
\hline Glycerine (kg) & $834,415.72$ & 5.70 & $4,756,169.61$ \\
\hline Monthly total profit (USD) & \multicolumn{2}{c}{$11,851,306.93$} \\
\hline Annual total profit (USD) & \multicolumn{2}{c}{$142,215,683.22$} \\
\hline
\end{tabular}

- $\quad$ The sale of total pure biodiesel could yield a monthly profit of US $\$ 6910,358.46$.

- The carbon credits and profit were calculated using Equations (5-7), which demonstrated that it would be possible to reduce the monthly and annual $\mathrm{CO}_{2}$ emissions by $19,976.09$ and $239,713.08 \mathrm{t}$, respectively, and to sell biodiesel at the monthly profit of USD $184,778.90$.

- Using Equation (8), the monthly and annual amount of produced glycerine was calculated to be $83,415.72$ and $10,012,988.64 \mathrm{~kg}$, respectively, which would yield a monthly profit of USD 4,756,169.61, according to Equation (9).

- The total annual and monthly profits would amount to the US \$11.851 and 143.652 million, respectively, which would represent a total decrease of $36.79 \%$ in the current fuel costs. 
Scenario 2: A fraction of the biodiesel produced is used to replace the biodiesel used in the B20 blend, and its out- and inflow balances are summarized in Tables 7 and 8 .

Table 7. Monthly balance of capital outflow cost for scenario 2 .

\begin{tabular}{|c|c|c|c|}
\hline Description & $\begin{array}{c}\text { Quantity } \\
\text { (Unit/Month) }\end{array}$ & Price (US\$) & $\begin{array}{c}\text { Unit Cost } \\
\text { (US\$/Month) }\end{array}$ \\
\hline Biodiesel plant & $1 / 120 *$ & $1,000,000.00$ & 8333.33 \\
\hline Maintenance (\%) & 4.00 & 8333.33 & 333.33 \\
\hline Pure diesel (L) & $26,666,666.68$ & 0.6897 & $18,392,982.46$ \\
\hline Ethanol (L) & $1,001,299$ & 0.5047 & $505,392.43$ \\
\hline \multicolumn{3}{|c|}{ Monthly total cost (US\$) } & $18,907,041.55$ \\
\hline \multicolumn{3}{|c|}{ Profit for this scenario (US\$) } & $13,310,350.88$ \\
\hline
\end{tabular}

Table 8. Monthly balance of capital inflow for scenario 2 .

\begin{tabular}{cccc}
\hline Description & $\begin{array}{c}\text { Quantity } \\
\text { (Unit/Month) }\end{array}$ & Price (US\$) & Profit (US\$/Month) \\
\hline Biodiesel excess (L) & $2,524,269.64$ & 0.7518 & $1,897,971.46$ \\
\hline Carbon Credit (t CO 2 ) & $19,976.09$ & 9.25 & $184,778.90$ \\
\hline Glycerine (kg) & $834,415.72$ & 5.70 & $4,756,169.61$ \\
\hline Monthly total profit (US\$) & \multicolumn{2}{c}{$11,686,504.16$} \\
\hline Monthly total saving (US\$) & $24,996,855.04$ \\
\hline Annual total saving (US\$) & \multicolumn{2}{c}{$299,962,260.48$} \\
\hline
\end{tabular}

- Pure diesel oil would only be sold by the Brazilian oil company (Petrobras) at 0.6897 US\$/L. As the monthly volume of diesel oil would represent $80 \%$ of the monthly volume of consumed fuel (26.666 million L), the monthly cost of fuel would be decreased to US $\$ 18.393$ million.

- Thus, the costs would follow the configuration presented in Table 7, and the difference in fuel outflows and economy with monthly diesel oil purchased of US $\$ 13,310,350.88$ would be achieved.

- The amount of biodiesel produced would be sufficient to meet the needs of biodiesel (20\%) mixed with diesel oil (80\%), and an excess of $37.87 \%$ pure biodiesel, which would amount to $2,524,269.64 \mathrm{~L} /$ month could be sold and generate a monthly profit of US $\$ 1,897,971.46$.

- Because the profits from the production and sale of glycerine and the carbon credits would be the same, the monthly profit of US $\$ 4,776,145.70$ should be added.

- The total monthly and annual amounts of US \$24.997 million and 300 million, respectively, would translate into the reduction in the total current cost of $78.84 \%$.

The amount that would have to be paid for the biodiesel plant would be insignificant, and it could be recuperated in 1.5-3 days of cash flow. We believe that both scenarios are very good; however, the second one would be twice as economically advantageous as the first. Thus, it would be the most economically viable one. Therefore, the economic and technical feasibility of the production of biodiesel from residual frying oil was demonstrated; moreover, using biodiesel instead of diesel oil would help to reduce pollutant emissions and public spending on health care. 
After implementing the policies based on environmental cost accounting, São Paulo could benefit as follows:

- $\quad$ Self-sufficiency in fuel supply;

- $\quad$ Could become a biodiesel supplier;

- Indiscriminate oil disposal would decrease;

- Expenses associated with the cost of the chemicals used for water and sewage treatment would decrease (much of the residual frying oil is currently discarded in inappropriate places that trap the waste into the sewage (Figure 7));

- The emissions of Sulphur and other polluting gases would decrease by more than $98 \%$ and $30 \%$, respectively $[12,15,73]$;

- The worldwide criticism associated with the direct use of cooking oil, such as soybean, olive, and corn oil, for the production of biodiesel would be avoided, the prices of these products would no longer increase, and therefore, they would no longer be inaccessible for the neediest communities;

- Agricultural expansion would decrease, as there would be no need to expand the arable area for soybean (and other oilseed) production for biodiesel fabrication;

- The deforestation of forest reserves to increase arable land for the production of oilseeds for biodiesel production would decrease;

- Water consumption for this agricultural expansion would also decrease;

- A non-food product would be obtained, in this case, oils intended for human consumption;

- The annual number of respiratory disease hospitalizations associated with fossil fuel pollutant gases would decrease by more than 9880 hospitalizations;

- Consequently, alleviating the burden on hospitals, and increasing the number of beds available for hospitalization for other diseases; and

- $\quad$ The annual amount of US $\$ 3,518,191.69$ that would otherwise be allocated to respiratory disease hospitalizations would be saved.

Thus, by mitigating these environmental effects, the image of São Paulo city could be improved.

A summary of the implementation stages of the green cost accounting policy is presented in Table 9, in order from the least to the most sustainable one.

In addition, Natali et al. [68] showed that children and adolescents account for $40 \%$ of hospitalizations for respiratory diseases and that these diseases correspond to $30 \%$ of total hospitalizations in São Paulo. Thus, as the reduction of gaseous emissions reduces hospitalizations for respiratory diseases, soon, hospital beds will be left to be used for other purposes.

According to Ravina et al. [69], the accounting of the effects of air pollution on human health costs is a useful indicator to support decisions and information at all management levels. Thus, with the economic advantages of ecological cost accounting presented in this work, profits can be redirected towards the expansion or construction of new hospitals, increasing the capacity for hospital beds in São Paulo $[7,35,44,67]$. This way, it showed how governments can better plan their investments to minimize hospitalizations for respiratory diseases and increase the number of hospital beds available for other diseases, such as COVID-19. 
Table 9. Summary of the stages of environmental cost accounting presented in this work.

\begin{tabular}{|c|c|c|c|c|}
\hline \multirow{2}{*}{ Field } & Stage 1 & Stage 2 & Stage 3 & Stage 4 \\
\hline & Unsustainable & \multicolumn{2}{|c|}{ Sustainable } & Fully Sustainable \\
\hline Environmental & $\begin{array}{ll}\text { - } & \text { misuse and incorrect disposal of } \\
\text { waste frying oils in sewage, } \\
\text { water bodies, or dumps; } \\
\text { - } \quad \text { excessive use of fossil fuel; } \\
\text { emission levels of pollutant gases } \\
\text { exceed WHO-acceptable levels }\end{array}$ & $\begin{array}{l}\text { public awareness via } \\
\text { motivational campaigns and } \\
\text { incentives for the proper } \\
\text { storage and collection of } \\
\text { residual frying oils }\end{array}$ & $\begin{array}{l}\text { - SP City Hall should start } \\
\text { collecting oils during waste } \\
\text { collection, using refuse trucks } \\
\text { equipped with frying oil } \\
\text { collection reservoirs; } \\
\text { - } \quad \text { beginning of production and } \\
\text { use of biodiesel as fuel; } \\
\text { - } \quad \text { zero uneven disposal of oil }\end{array}$ & $\begin{array}{ll}- & \text { continuous operation of biodiesel } \\
\text { production plant; } \\
-\quad \text { complete replacement of fossil fuel by } \\
\text { biodiesel blend; } \\
-\quad \text { gain } 239,713 \text { carbon credits per year; } \\
-\quad \text { reduction in pollutant emissions of at } \\
\text { least } 30 \% \text {; } \\
\text { elimination of disposal of frying oil in } \\
\text { sewage, garbage, soil, and other } \\
\text { unacceptable places }\end{array}$ \\
\hline Economic & $\begin{array}{l}\text { - high costs associated with the fuel } \\
\text { purchase, removal of oil during } \\
\text { water and wastewater treatment, } \\
\text { and hospitalizations of patients } \\
\text { owing to conditions caused by the } \\
\text { emission of pollutants }\end{array}$ & $\begin{array}{l}\text { costs associated with } \\
\text { advertising, lectures, } \\
\text { and building the } \\
\text { biodiesel plant }\end{array}$ & $\begin{array}{l}\text { zero cost associated with the } \\
\text { collection of waste frying oil, } \\
\text { water, and sewage treatment, } \\
\text { and hospitalization sowing to } \\
\text { conditions caused by } \\
\text { gaseous emissions }\end{array}$ & $\begin{array}{l}\text { - annual gain of US } \$ 299.9 \text { million from the } \\
\text { sale of excess biodiesel, carbon credits, } \\
\text { and glycerine, and fuel acquisition savings; } \\
\text { - } \quad \text { decrease in annual hospitalization cost by } \\
\text { US } \$ 3.518 \text { million; } \\
\text { - estimated total annual profit of US } \\
\text { \$300 million }\end{array}$ \\
\hline
\end{tabular}




\section{Conclusions}

When analyzing the database of airborne pollutant gases in São Paulo city, it was noted that the emission levels of $\mathrm{PM}_{10}, \mathrm{PM}_{2.5}$, and $\mathrm{NO}_{2}$ were higher than the WHOestablished values throughout the study period, indicating that the air quality in São Paulo city was poor throughout the study period. During the study period, approximately 330,000 respiratory disease hospitalizations were recorded in São Paulo city, which translated into the total cost of US $\$ 117$ million for the Brazilian government, and positively correlated with the $\mathrm{PM}_{10}, \mathrm{PM}_{2.5}, \mathrm{SO}_{2}, \mathrm{CO}$, and $\mathrm{NO}_{2}$ pollutant gaseous emissions.

The biodiesel produced from the waste frying oils were within the standard limits, and the total monthly produced volume was estimated to be $9191.2 \mathrm{~m}^{3}$; moreover, the associated annual carbon credits would equal $239,713 \mathrm{t} \mathrm{CO}_{2}$, and the total pollutant emissions would decrease by more than $30 \%$. Environmental cost accounting has revealed that the annual number of respiratory disease hospitalizations could decrease by 9880 , and the associated health care cost would decrease by US $\$ 3.518$ million per year; moreover, the sale of the excess biodiesel, carbon credits, and glycerine, as well as the fuel acquisition savings would result in the annual profit of approximately US $\$ 300$ million. In addition, the city's reputation and the quality of life of the São Paulo city residents could improve.

Author Contributions: Conceptualization, J.C.C.S.; A.C.M. and L.L.H.; Methodology, A.C.M.; L.L.H. and J.C.C.S.; Formal Analysis, L.S.; C.L.K.Y.; A.C.M. and J.C.C.S.; Resources, A.C.M.; L.S.; C.L.K.Y.; F.T.B. and J.C.C.S.; Writing-Original Draft Preparation, D.d.F.C.; F.T.B.; J.C.C.S. and L.L.H.; WritingReview and Editing; D.d.F.C.; C.L.K.Y.; F.T.B., E.B.T. and J.C.C.S.; Supervision, L.L.H.; F.T.B.; E.B.T. and J.C.C.S.; Project Administration, E.B.T.; F.T.B. and J.C.C.S. All authors have read and agreed to the published version of the manuscript.

Funding: This research received the external funding of the National Council for Scientific and Technological Development (CNPq), Brasilia, Brazil, Financial Code: 305987/2018-6.

Institutional Review Board Statement: Brazilian ethic review committee-CONEP, Plataforma Brasil: P32432814.8.0000.5511 of 16 April 2014.

Informed Consent Statement: Not applicable.

Data Availability Statement: Not applicable.

Acknowledgments: The authors thank the University of São Paulo (USP) and the Fundação Carlos Vanzolini (FCAV) for financial support. This study was financed in part by the Coordenação de Aperfeiçoamento de Pessoal de Nível Superior-Brasil (CAPES)-Finance Code 001 and National Council for Scientific and Technological Development (CNPq), Brasilia, Brazil, Financial Code: 305987/2018-6. our research group would like to thank, in memory, Silvério Catureba da Silva Filho for his years of contribution to the development and application of technologies for sustainable development. We will never forget you.

Conflicts of Interest: The authors declare no conflict of interest.

\section{References}

1. de Oliveira Neto, G.C.; Correia, J.M.F.; Silva, P.C.; Sanches, A.G.O.; Lucato, W.C. Cleaner production in the textile industry and its relationship to sustainable development goals. J. Clean. Prod. 2019, 228, 1514-1525. [CrossRef]

2. Leite, R.; Amorim, M.; Rodrigues, M.; Oliveira Neto, G. Overcoming barriers for adopting cleaner production: A case study in Brazilian small metal-mechanic companies. Sustainability 2019, 11, 4808. [CrossRef]

3. de Paoli, F.M.; de Oliveira Neto, G.C.; Lucato, W.C. Economic and environmental gains resulting from the utilization of the design for the environment (DfE). Espacios 2013, 34, 1-11.

4. Oliveira Neto, G.C.; Chaves, L.E.C.; Pinto, L.F.; Santana, J.C.C.; Amorim, M.P.C.; Rodrigues, M.J.F. Economic, environmental and social benefits of adoption of pyrolysis process of tires: A feasible and ecofriendly mode to reduce the impacts of scrap tires in Brazil. Sustainability 2019, 11, 2076. [CrossRef]

5. Benvenga, M.A.C.; Librantz, A.F.H.; Santana, J.C.C.; Tambourgi, E.B. Genetic algorithm applied to study of the economic viability of alcohol production from Cassava root from 2002 to 2013. J. Clean. Prod. 2016, 113, 483-494. [CrossRef]

6. Guerhardt, F.; Silva, T.A.F.; Gamarra, F.M.C.; Ribeiro, S.E.R., Jr.; Llanos, S.A.V.; Quispe, A.P.B.; Vieira, M., Jr.; Tambourgi, E.B.; Santana, J.C.C.; Vanalle, R.M. A smart grid system for reducing energy consumption and energy cost in buildings in São Paulo, Brazil. Energies 2020, 13, 3874. [CrossRef] 
7. Santana, J.C.C.; Miranda, A.C.; Yamamura, C.L.K.; Silva Filho, S.C.; Tambourgi, E.B.; Ho, L.L.; Berssaneti, F.T. Effects of air pollution on human health and costs: Current situation in São Paulo, Brazil. Sustainability 2020, 12, 4875. [CrossRef]

8. Reşitoğlu, İ.A.; Altinişik, K.; Keskin, A. The pollutant emissions from diesel-engine vehicles and exhaust after treatment systems. Clean Technol. Environ. Policy 2015, 17, 15-27. [CrossRef]

9. Pereira, R.Q.; Tulcan, O.E.P.; Fellows, C.E.; Lameira, V.J.; Quelhas, O.L.G.; de Aguiar, M.E.; do Espirito Santo Filho, D.M. Sustainability and mitigation of greenhouse gases using ethyl beef tallow biodiesel in energy generation. J. Clean. Prod. 2012, 29-30, 269-276. [CrossRef]

10. WHO (World Health Organization). Air Quality Guidelines; Global Update 2005. Particulate Matter, Ozone, Nitrogen Dioxide and Sulfur Dioxide; World Health Organization: Copenhagen, Denmark, 2005.

11. Hajjari, M.; Tabatabaei, M.; Aghbashlo, M.; Ghanavati, H. A review on the prospects of sustainable biodiesel production: A global scenario with an emphasis on waste-oil biodiesel utilization. Renew. Sustain. Energy Rev. 2017, 72, 445-464. [CrossRef]

12. Selley, L.; Phillips, D.H.; Mudway, I. The potential of omics approaches to elucidate mechanisms of biodiesel-induced pulmonary toxicity. Part. Fibre Toxicol. 2019, 16, 1-16. [CrossRef]

13. da Silva, M.J.; de Souza, S.N.M.; Souza, A.A.; Martins, G.I.; Secco, D. Engine-generator diesel cycle under five proportions of biodiesel and diesel. Rev. Bras. Eng. Agrícola Ambient. 2012, 16, 320-326. [CrossRef]

14. Reis, H.; Reis, C.; Sharip, A.; Reis, W.; Zhao, Y.; Sinclair, R.; Beeson, L. Diesel exhaust exposure, its multi-system effects, and the effect of new technology diesel exhaust. Environ. Int. 2018, 114, 252-265. [CrossRef] [PubMed]

15. Silva Filho, S.C.; Miranda, A.C.; Silva, T.A.F.; Calarge, F.A.; Souza, R.R.; Santana, J.C.C.; Tambourgi, E.B. Environmental and techno-economic considerations on biodiesel production from waste cooking oil in São Paulo city. J. Clean. Prod. 2018, 183, 1034-1043. [CrossRef]

16. Hasan, M.M.; Rahman, M.M. Homogeneous charge compression ignition combustion: Advantages over compression ignition combustion, challenges and solutions. Renew. Sustain. Energy Rev. 2016, 57, 282-291. [CrossRef]

17. Hasan, M.M.; Rahman, M.M. Performance and emission characteristics of biodiesel-diesel blend and environmental and economic impacts of biodiesel production: A review. Renew. Sustain. Energy Rev. 2017, 74, 938-948. [CrossRef]

18. Chua, C.B.H.; Lee, H.M.; Low, J.S.C. Life cycle emissions and energy study of biodiesel derived from waste cooking oil and diesel in Singapore. Int. J. Life Cycle Assess. 2010, 15, 417-423. [CrossRef]

19. Miranda, A.C.; Silva Filho, S.C.; Tambourgi, E.B.; Santana, J.C.C.; Vanalle, R.M.; Gherhardt, F. Analysis of the costs and logistics of biodiesel production from used cooking oil in the metropolitan region of Campinas (Brazil). Renew. Sustain. Energy Rev. 2018, 88, 373-379. [CrossRef]

20. Santos, U.P.; Braga, A.L.F.; Garcia, M.L.B.; Pereira, L.A.A.; Lin, C.A.; Chiarelli, P.A.; de André, C.A.S.; de André, P.A.; Singer, J.M.; Saldiva, P.H.N. Exposure to fine particles increases blood pressure of hypertensive outdoor workers: A panel study. Environ. Res. 2019, 174, 88-94. [CrossRef]

21. Živković, S.B.; Veljković, M.V.; Banković-Ilić, I.B.; Krstić, I.M.; Konstantinović, S.S.; Ilić, S.B.; Avramović, J.M.; Stamenković, O.S.; Veljković, V.B. Technological, technical, economic, environmental, social, human health risk, toxicological and policy considerations of biodiesel production and use. Renew. Sustain. Energy Rev. 2017, 79, 222-247. [CrossRef]

22. Almeida, P.F.; Araújo, M.G.O.; Santana, J.C.C. Collagen extraction from chicken feet for jelly production. Acta Sci. Technol. 2012, 34, 345-351. [CrossRef]

23. Rosa, J.M.; Tambourgi, E.B.; Santana, J.C.C.; de Campos Araujo, M.; Ming, W.C.; Trindade, N. Development of colors with sustainability: A comparative study between dyeing of cotton with reactive and vat dyestuffs. Text. Res. J. 2014, 84, 1009-1017. [CrossRef]

24. Brodny, J.; Tutak, M. Analysis of the diversity in emissions of selected gaseous and particulate pollutants in the European Union countries. J. Environ. Manag. 2019, 231, 582-595. [CrossRef]

25. De Marco, A.; Proietti, C.; Anav, A.; Ciancarella, C.; D’Elia, I.; Fares, S.; Fornasier, M.F.; Fusaro, L.; Gualtieri, M.; Manes, F.; et al. Impacts of air pollution on human and ecosystem health, and implications for the National Emission Ceilings Directive: Insights from Italy. Environ. Int. 2019, 125, 320-333. [CrossRef] [PubMed]

26. Yu, T.; Wang, W.; Ciren, P.; Zhu, Y. Assessment of human health impact from exposure to multiple air pollutants in China based on satellite observations. Int. J. Appl. Earth Obs. Geoinf. 2016, 52, 542-553. [CrossRef]

27. Terra, J.D.R.; Berssaneti, F.T. Application of lean healthcare in hospital services: A review of the literature (2007 to 2017). Production 2018, 28, e20180009. [CrossRef]

28. Andrade, M.F.; Kumar, P.; Freitas, E.D.; Ynoue, R.Y.; Martins, J.; Nogueira, T.; Martinez, P.P.; Miranda, R.M.; Albuquerque, T.; Gonçalvez, F.L.T.; et al. Air quality in the megacity of São Paulo: Evolution over the last 30 years and future perspectives. Atmos. Environ. 2017, 159, 66. [CrossRef]

29. Votto, R.; Lee Ho, L.; Berssaneti, F.B. Applying and assessing performance of earned duration management control charts for EPC project duration monitoring. J. Constr. Eng. Manag. 2020, 146, 04020001. [CrossRef]

30. Miranda, R.M.; Lopes, F.; Rosario, N.E.; Yamasoe, M.A.; Landulfo, E.; Andrade, M.F. The relationship between aerosol particles chemical composition and optical properties to identify the biomass burning contribution to fine particles concentration: A case study for Sao Paulo city, Brazil. Environ. Monit. Assess. 2017, 189, 9-15. [CrossRef] [PubMed]

31. Vanalle, R.M.; Lucato, W.C.; Ganga, G.M.D.; Alves Filho, A.G. Risk management in the automotive supply chain: An exploratory study in Brazil. Int. J. Prod. Res. 2020, 58, 783-799. [CrossRef] 
32. Fajersztajn, L.; Veras, M.; Saldiva, P.H.N. Como as cidades podem favorecer ou dificultar a promoção da saúde de seus moradores? Estud. Avançados 2016, 30, 7-27. [CrossRef]

33. Santana, J.C.C.; Gardim, R.B.; Almeida, P.F.; Borini, G.B.; Quispe, A.P.B.; Llanos, S.A.V.; Heredia, J.A.; Zamuner, S.; Gamarra, F.M.C.; Farias, T.M.B.; et al. Valorization of chicken feet by-product of the poultry industry: High qualities of gelatin and biofilm from extraction of collagen. Polymers 2020, 12, 529. [CrossRef] [PubMed]

34. Mantovani, K.C.C.; Nascimento, L.F.C.; Moreira, D.S.; Vargas, N.P.; da Silva Vieira, L.C.P.F. Poluentes do ar e internações devido a doenças cardiovasculares em São José do Rio Preto, Brasil. Ciência Saúde Coletiva 2016, 21, 509-516. [CrossRef] [PubMed]

35. Paiva, R.F.P.S. Hospital morbidity due to diseases associated with air pollution in the city of Volta Redonda, Rio de Janeiro: Cases and economic cost. Cad. Saúde Coletiva 2014, 22, 127-133. [CrossRef]

36. Liaquat, A.M.; Kalam, M.A.; Masjuki, M.H. Potential emissions reduction in road transport sector using biofuel in developing countries. Atmos. Environ. 2010, 44, 3869-3877. [CrossRef]

37. Vilas Boas, D.S.; Matsuda, M.; Toffoletto, O.; Garcia, M.L.B.; Saldiva, P.H.N.; Marquezini, M.V. Workers of São Paulo city, Brazil, exposed to air pollution: Assessment of genotoxicity. Mutat. Res. Genet. Toxicol. Environ. Mutagenesis 2018, 834, 18-24. [CrossRef]

38. Vormittag, E.M.P.A.; Rodrigues, C.G.; de André, P.A.; Saldiva, P.H.N. Assessment and valuation of public health impacts from gradual biodiesel implementation in the transport energy matrix in Brazil. Aerosol Air Qual. Res. 2018, 18, 2375-2382. [CrossRef]

39. ANP (National Agency of Petroleum). ANP Resolution-2004. Available online: http://www.anp.gov.br/petro/legis_biodiesel (accessed on 20 February 2020).

40. Arbex, M.A.; Santos, U.P.; Martins, L.C.; Saldiva, P.H.N.; Pereira, L.A.A.; Braga, A.L.F. Air pollution and the respiratory system. J. Bras. Pneumol. 2012, 38, 643-655. [CrossRef]

41. Kunzli, N.; Perez, L.; Rapp, R. Air quality and health. Eur. Respir. Soc. 2014, 44, 614-626.

42. Costa, R.G.R.; Silva, C.G.T.; Cohen, S.C. A origem do caos-A crise de mobilidade no Rio de Janeiro e a ameaça à saúde urbana. Cad. Metrópole 2013, 15, 411-431. [CrossRef]

43. Gehring, U.; Wijga, A.H.; Brauer, M.; Fischer, P.; Jongste, J.C.; Kerkhof, M.; Oldenwening, M.; Smit, H.A.; Brunekreef, B. Trafficrelated air pollution and the development of asthma and allergies during the first 8 years of life. Am. J. Respir. Crit. Care Med. 2010, 181, 596-603. [CrossRef]

44. Ko, F.W.; Tam, W.; Wong, T.W.; Chan, D.P.; Tung, A.H.; Lai, C.K.; Hui, D.S. Temporal relationship between air pollutants and hospital admissions for chronic obstructive pulmonary disease in Hong Kong. Thorax 2007, 62, 780-785. [CrossRef] [PubMed]

45. Andersen, Z.J.; Hvidberg, M.; Jensen, S.S.; Ketzel, M.; Loft, S.; Sørensen, M.; Tjønneland, A.; Overvad, K.; Raaschou-Nielsen, O. Chronic obstructive pulmonary disease and long-term exposure to traffic-related air pollution: A cohort study. Am. J. Respir. Crit. Med. 2011, 183, 455-461. [CrossRef] [PubMed]

46. Hu, G.; Zhou, Y.; Tian, J.; Yao, W.; Li, J.; Li, B.; Ran, P. Risk of COPD from exposure to biomass smoke: A metaanalysis. Chem. Rev. 2010, 138, 20-31.

47. Pandya, R.J.; Solomon, G.; Kinner, A.; Balmes, J.R. Diesel exhaust and asthma: Hypotheses and molecular mechanism of action. Environ. Health Perspect. 2002, 110 (Suppl. 1), 103-112. [CrossRef] [PubMed]

48. Xia, B.; Zhou, Y.; QingyangZhu, O.; Zhao, Y.; Wang, Y.; Ge, W.; Yang, Q.; Zhao, Y.; Wang, P.; Si, J.; et al. Personal exposure to $\mathrm{PM}_{2.5}$ constituents associated with gestational blood pressure and endothelial dysfunction. Environ. Pollut. 2019, 250, 346-356. [CrossRef]

49. Erickson, A.C.; Brauer, M.; Christidis, T.; Pinault, L.; Crouse, D.L.; Donkelaar, A.; Weichenthal, S.; Pappin, A.; Tiepkema, M.; Martin, R.V.; et al. Evaluation of a method to indirectly adjust for unmeasured covariates in the association between fine particulate matter and mortality. Environ. Res. 2019, 175, 108-116. [CrossRef]

50. Polezer, G.; Tadano, Y.; Siqueira, H.V.; Godoi, A.F.L.; Yamamoto, C.I.; De André, P.A.; Pauliquevis, T.; Andrade, M.F.; Oliveira, A.; Saldiva, P.H.N.; et al. Assessing the impact of PM 2.5 on respiratory disease using artificial neural networks. Environ. Pollut. 2018, 235, 394-403. [CrossRef]

51. Pinheiro, S.L.L.A.; Saldiva, P.H.N.; Schwartz, J.; Zanobetti, A. Isolated and synergistic effects of PM10 and average temperature on cardiovascular and respiratory mortality. Rev. Saude Publica 2014, 12, 756-765. [CrossRef]

52. Freitas, C.U.; Leon, A.P.; Juger, W.; Gouveia, N. Poluição do ar e impactos na saúde em Vitória, Espírito Santo. Rev. Saude Publica 2016, 50, 1-9. [CrossRef]

53. Mascarenhas, M.D.M.; Vieira, L.C.; Lanzieri, T.M.; Leal, A.P.P.R.; Duarte, A.F.; Hatch, D.L. Poluição atmosférica devida à queima de biomassa florestal e atendimentos de emergência por doença respiratória em Rio Branco, Brasil—Setembro, 2005. J. Bras. Pneumol. 2008, 34, 42-46. [CrossRef] [PubMed]

54. Berssaneti, F.T.; Assumpção, A.; Nakao, O.S. Engineering, procurement and construction (EPC): What are the variables that impact the success of the projects currently running in Brazil? Gest. Prod. 2014, 21, 95-109. [CrossRef]

55. Santana, J.C.C.; Guerhardt, F.; Franzini, C.E.; Lee Ho, L.; Ribeiro Junior, S.E.R.; Canovas, G.; Yamamura, C.L.K.; Vanalle, R.M.; Berssaneti, F.T. Refurbishing and recycling of cell phones as a sustainable process of reverse logistics: A case study in Brazil. J. Clean. Prod. 2021, 283, 124585. [CrossRef]

56. Berssaneti, F.T.; Berger, S.; Saut, A.M.; Vanalle, R.M.; Santana, J.C.C. Value generation of remanufactured products: Multi-case study of third-party companies. Sustainability 2019, 11, 584. [CrossRef]

57. IBGE (Brazilian Institute of Geography and Statistic). Panorama over the City of São Paulo. Available online: https: / cidades. ibge.gov.br/brasil/sp/sao-paulo/panorama (accessed on 10 November 2020). 
58. SP City Hall. Data on the City of São Paulo. Available online: http:/ / www.capital.sp.gov.br/ (accessed on 8 March 2020).

59. Severo, J.B., Jr.; Almeida, S.S.; Narain, N.; Souza, R.R.; Santana, J.C.C.; Tambourgi, E.B. Wine clarification from Spondias mombin L. pulp by hollow fiber membrane system. Process. Biochem. 2007, 42, 1516-1520. [CrossRef]

60. Lucato, W.C.; Vieira, M., Jr.; Vanalle, R.M.; Salles, J.A.A. Model to measure the degree of competitiveness for auto parts manufacturing companies. Int. J. Prod. Res. 2012, 50, 5508-5522. [CrossRef]

61. CETESB. Environmental Sanitation Technology Company. Available online: http:/ / www.cetesb.gov.br (accessed on 5 July 2020).

62. CONAMA (National Council of Environment). Brazilian Environmental Policies. Available online: http://www.mma.gov.br/ conama (accessed on 9 July 2020).

63. Solé, D.; Camelo-Nunes, I.C.; Wandalsen, G.F.; Pastorino, A.C.; Jacob, C.M.A.; Gonzalez, C.; Wandalsen, N.F.; Rosário Filho, N.A.; Fischer, G.B.; Naspitz, C.K. Prevalence of symptoms of asthma, rhinitis, and atopic eczema in Brazilian adolescents related to exposure to gaseous air pollutants and socioeconomic status. J. Investig. Allergol. Clin. Immunol. 2007, 17, 6-13. [PubMed]

64. Locosselli, G.M.; Camargo, E.P.; Moreira, T.C.L.; EnzoTodesco, E.; Andrade, M.F.; de André, C.D.S.; de André, P.A.; Singer, J.M.; Ferreira, L.S.; Saldiva, P.N.H.; et al. The role of air pollution and climate on the growth of urban trees. Sci. Total Environ. 2019, 666, 652-661. [CrossRef]

65. Sera, F.; Ben Armstrong, A.T.; Vicedo-Cabrera, A.M.; Åström, C.; Bell, M.L.; Chen, B.Y.; Coelho, M.S.Z.S.; Correa, P.M.; Cruz, J.C.; Dang, T.N.; et al. How urban characteristics affect vulnerability to heat and cold: A multi-country analysis. Int. J. Epidemiol. 2019, 48, 1101-1112. [CrossRef]

66. Zhao, Q.; Li, S.; Coelho, M.S.Z.S.; Saldiva, P.H.N.; Hu, K.; Abramson, M.J.; Huxley, R.R.; Guo, Y. Assessment of intraseasonal variation in hospitalization associated with heat exposure in Brazil. JAMA Netw. Open 2019, 2, e187901. [CrossRef]

67. Gao, J.; Kovats, S.; Vardoulakis, S.; Wilkinson, P.; Woodward, A.; Li, J.; Gu, S.; Liu, X.; Wu, H.; Wang, J.; et al. Public health co-benefits of greenhouse gas emissions reduction: A systematic review. Sci. Total Environ. 2018, 627, 388-402. [CrossRef] [PubMed]

68. Ravina, M.; Panepinto, D.; Zanetti, M.C. DIDEM-An integrated model for comparative health damage costs calculation of air pollution. Atmos. Environ. 2018, 173, 81-95. [CrossRef]

69. Natali, R.M.T.; Santos, D.D.P.S.; Fonseca, A.M.C.; Filomeno, G.C.M.; Figueiredo, A.H.A.; Terrivel, P.M.; Massoni, K.M.; Braga, A.L.F. Perfil de internações hospitalares por doenças respiratórias em crianças e adolescentes da cidade de São Paulo, 2000-2004. Rev. Paul. Pediatr. 2011, 29, 584-590. [CrossRef]

70. Duhanyan, N.; Roustan, Y. Below-cloud scavenging by rain of atmospheric gases and particulates. Atmos. Environ. 2011, 45, 7201-7217. [CrossRef]

71. Xu, D.; Ge, B.; Chen, X.; Sun, Y.; Cheng, N.; Li, M.; Pan, X.; Ma, Z.; Pan, Y.; Wang, Z. Multimethod determination of the below-cloud wet scavenging coefficients of aerosols in Beijing, China. Atmos. Chem. Phys. 2019, 19, 15569-15581. [CrossRef]

72. Gonçalves, F.L.T.; Coelho, M.S.Z.S. Variação da morbidade de doenças respiratórias em função da variação da temperatura entre os meses de abril e maio em São Paulo. Ciência Nat. 2010, 32, 103-118.

73. Giraçol, J.; Passarini, K.C.; Silva Filho, S.C.; Calarge, F.A.; Tambourgi, E.B.; Santana, J.C.C. Reduction in ecological cost through biofuel production from cooking oils: An ecological solution for the city of Campinas, Brazil. J. Clean. Prod. 2011, 19, 1324-1329. [CrossRef]

74. Jorge, H.; Lopes, M.R.V. Avaliação de óleos e gorduras de frituras coletados no comércio de São José do Rio Preto-SP. Aliment. Nutr. Araraquara 2009, 14, 149-156.

75. Tavares, M.; Gonzalez, E.; da Silva, M.L.P.; Barsotti, R.C.F.; Kumagai, E.E.; Caruso, M.S.F.; Aued-Pimentel, S.; Ruvieri, V.; de Souza, D.L. Assessment of food frying-oils and-fats marketed in Santos metropolitan area, São Paulo state. Rev. Inst. Adolfo Lutz 2007, 66, 40-44.

76. Rabelo, R.A.; Ferreira, M.O. Coleta Seletiva de Óleo Residual de Fritura para Aproveitamento Industrial. Universidade Católica de Goiás. 2008. Available online: http:/ / www.pucgoias.edu.br/ucg (accessed on 2 October 2019).

77. Thode Filho, S.; Santo, A.S.S.; Almeida, T.M.; Silva, E.R. Technology applied to environmental management and processing of vegetable oil residual in the state of Rio de Janeiro. Rev. Eletrônica Gestão Educ. Tecnol. Ambient. 2013, 15, 3026-3035. [CrossRef]

78. Castro, E.R.; Fernandes, F.C.; Ramos, M.V. Desconhecimento é a maior barreira na produção de biocombustível oriundo de óleo reutilizado em Mogi das Cruzes/SP. In Proceedings of the IX Sintagro-Simpósio Nacional de Tecnologia em Agronegócio, Botucatu, Brazil, 22-24 June 2017.

79. Gouveia, N.; Corallo, F.P.; Leon, A.C.P.; Junger, W.; Freitas, C.U. Air pollution and hospitalizations in the largest Brazilian metropolis. Rev. Saude Publica 2017, 51. [CrossRef] 